\title{
OS CAMPOS DA RAIA CENTRAL NA PERSPECTIVA DO DESENVOLVIMENTO RURAL
}

\author{
CARMINDA CAVACO
}

1. SUbDESENVOLVIMENTO E DEPRESSÃo Socio-económiCa dA FronteiRa LUSO-ESPANHOLA

A fronteira Portugal-Espanha identifica-se, de há muito, como um longo corredor deprimido em termos de desenvolvimento, fortemente marcado pelo êxodo da população (com os seus efeitos no envelhecimento, na redução da natalidade e na anulação dos saldos fisiológicos) e em vias de desertificação humana, de continuidade apenas pontualmente perturbada.

Esta raia deprimida contrasta com a situação socio-económica da maior parte das regiões de fronteira da Comunidade Económica Europeia, que se distinguem pelo seu nível de desenvolvimento, sendo os IS (índices sintéticos) superiores ao da Comunidade e mesmo aos dos próprios países; são excepção as da Irlanda-Reino Unido e as da Espanha-França, mas sobretudo as da Espanha-Portugal, os dois países ibéricos destacando-se também na CEE12 pelos seus índices de perificidade.

$\mathrm{Na}$ origem desta situação relevam-se as estratégias de «terra queimada»/segurança dos dois estados peninsulares, as políticas de desenvolvimento essencialmente periférico e marítimo, o receio da concorrência, traduzido na persistente fraqueza das suas trocas legais de bens e serviços e na independência das respectivas políticas regionais. As áreas de fronteira tornaram-se desse modo ultraperiferias de regiões já 
bastante periféricas e marginalizadas, a nível nacional e comunitário, de que nem mesmo o pequeno troço da fronteira a norte, na secção jusante do rio Minho, e o extremo da fronteira sul, junto do estuário do Guadiana, são verdadeiras excepções.

E certo que as condições do meio natural não são particularmente propícias ao desenvolvimento: terras altas, movimentadas, de encostas declivosas e vales encaixados; solos esqueléticos e pobres; climas de acentuada tonalidade continental, com pluviosidade reduzida e irregular, Invernos rudes e Verões muito quentes e secos; ausência de recursos minerais valiosos, etc. Tais condicionantes físicas só localmente foram atenuadas pela intervenção humana, como na Terra de Soria e sobretudo na área do plano de desenvolvimento de Badajoz, assentes largamente nos aproveitamentos hidroagrícolas do Tejo (regadios do Arrago e do Alagón: 8700 ha e 33000 ha, respectivamente) e do Guadiana, a que correspondem no território português os pequenos aproveitamentos da Idanha e do Caia.

Por tudo isto, a fronteira Portugal-Espanha suscitou fundamentalmente trocas clandestinas de bens, de âmbito local ou mais vastas, já que potencialmente animadas pelas cidades espanholas de certa importância que a acompanham à distância, sem paralelo do lado português, mesmo tendo em conta a menor concentração do povoamento no território nacional. Do mesmo modo, os movimentos de pessoas através da fronteira, em larga medida também eles clandestinos, envolveram essencialmente trabalhadores agrícolas e da construção civil, que em Espanha ou mais além, em França e noutros países europeus, encontraram emprego e salários considerados compensadores, em confronto com as alternativas ou a falta delas na região ou no conjunto territorial português.

Digamos que as populações locais, pouco preocupadas com soberanias nacionais, procuraram ultrapassar a barreira político-administrativa e manter relações, tão frequentes e úteis no imediato quanto possivel, com as suas vizinhas do outro lado da fronteira: nas suas estratégias de sobrevivência incluíram o aproveitamento das potencialidades criadas pela sua própria impermeabilidade, da pequena candonga (diferenças de preços de bens de consumo) a serviços (qualidade e acessi- 
bilidade, como no caso dos servǐços de saúde), a negócios de vulto obscuros, arriscados mas lucrativos, e à condução de fluxos emigratórios clandestinos, nos anos sessenta.

Mas os principais fluxos económicos de âmbito regional não atravessavam a fronteira, que separava estruturas espaciais diferentes e quase independentes: a sua impermeabilidade era então quase total, como o expressam as próprias redes viárias, predominantemente de orientação norte-sul, com os principais nós algo afastados dos limites territoriais dos dois países e ramais secundários dirigidos às aldeias mais periféricas. Os pontos de passagem de fluxos longos com ligação à Europa, de mercadorias e pessoas (turismo de passagem, incluindo o pseudoturismo estival de emigrantes), pela ruptura introduzida pelos serviços alfandegários e policiais na fluidez rodoviária e ferroviária, identificam-se com pequenos oásis de acentuado dinamismo demográfico, comercial, bancário, da restauração e hotelaria..., pelo reforço dos efeitos dos intercâmbios de âmbito local, como em Vilar Formoso-Fuentes d'Oñoro.

\section{A ÁREa RaIana da BeIRA, UM EspaÇo Essencialmente RuRaL}

A Beira Interior considerada nesta análise corresponde ao sector central da zona fronteiriça de Portugal-Espanha, entre os rios Douro e Tejo, um dos de mais acentuada depressão socio-económica, que contrasta inclusivamente com outras áreas dos distritos a que pertence (Guarda e Castelo Branco), os quais compreendem algumas manchas de agricultura próspera, núcleos industriais de certa importância e cidades pequenas mas relativamente dinâmicas. Por comodidade no uso de informação estatística, retiveram-se os concelhos de Almeida, Sabugal, Penamacor e Idanha: o de Figueira de Castelo Rodrigo já faz parte da região do Douro. São todos eles concelhos marcadamente rurais. Consideremos como indicadores da sua ruralidade as percentagens das respectivas superfícies integradas em explorações agrícolas, as correspondentes às áreas agroflorestais e a estrutura do povoamento.

A superfície das explorações abrangia em 1979, quando do RAC, mais de $30 \%$ das suas superfícies (fig. 1) e nos concelhos mais meridionais rondava os $60 \%$, enquanto as áreas 


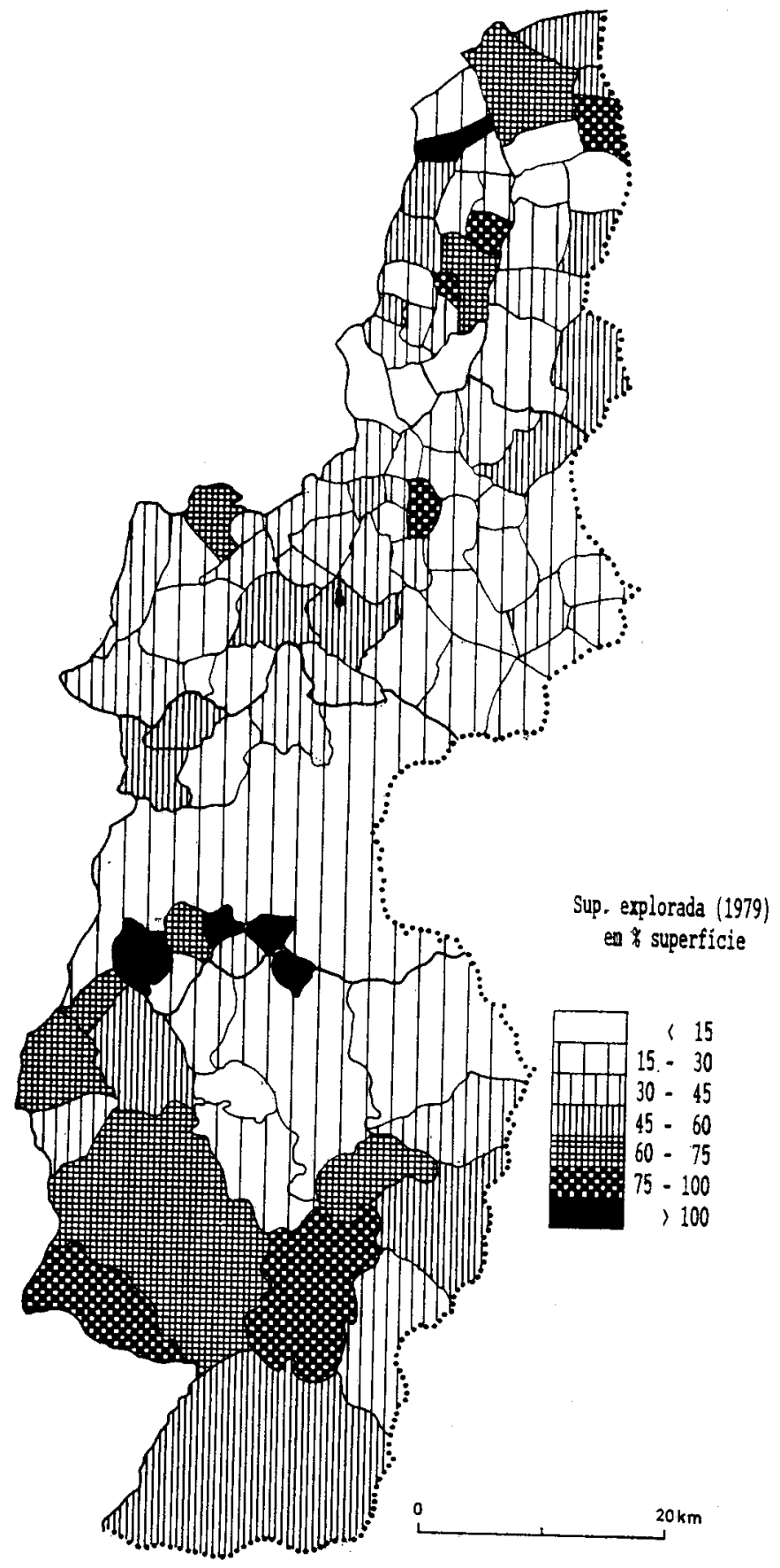

Fig. 1-A superfície das explorações agrícolas, recenseadas em 1979, em percentagem da superfície total das freguesias. 
agroflorestais ultrapassavam mais de $\mathbf{5 0 \%}$ nestes e apenas no de Sabugal se reduziam a menos de $25 \%$ (quadro I). Estes últimos valores - simples ordens de grandeza da ocupação do espaço - deverão ser ponderados pelas taxas de arborização e de incultos, aquelas já particularmente elevadas no início dos anos setenta nos concelhos de Sabugal e Idanha, bem como as últimas em todos eles, com excepção de Idanha. Penamacor e Idanha foram, aliás, identificados recentemente (Portaria $513 / 89$ ) como concelhos em que a ocupação do solo com espécies florestais de rápido crescimento exploradas em revoluções curtas abrangem área superior a 25\% das áreas totais, apesar das suas modestas potencialidades para o Eucaliptus globulus.

\section{QUADRO I}

A ocupação agroflorestal dos concelhos

\begin{tabular}{|c|c|c|c|c|c|}
\hline \multicolumn{2}{|c|}{$\%$ das superfícies concelhias } & Almeida & Sabugal & Penamacor & Idanha \\
\hline Ārea das explorações & $(1979)$ & 39,5 & 31,4 & 58,7 & 62,5 \\
\hline Ārea agroflorestal & $(1979)$ & 32,1 & 22,8 & 54,1 & 57,9 \\
\hline Taxa de arborização & $(1974)$ & 18,2 & 28,8 & 17,1 & 29,6 \\
\hline Taxa de incultos & $(1974)$ & 30,6 & 27,4 & 32,7 & 12,1 \\
\hline
\end{tabular}

Descendo a análise às freguesias, constatamos que as superfícies das explorações representavam, em 1979, parcelas sempre significativas das superfícies totais, embora mais elevadas nas áreas bastante utilizadas pelas suas componentes agrícola, florestal e de pasto, como ocorre em muitas do concelho de Idanha, mas sobretudo nas muito pequenas, que inclusivamente contêm as sedes de explorações que se estendem por freguesias próximas (freguesias das periferias dos concelhos de Idanha e Penamacor); os valores percentuais são, pelo contrário, modestos nas freguesias dominadas por áreas de relevo mais movimentado (Monsanto, Penha Garcia, Malcata, etc.), de utilização mais extensiva e colectiva (explorações florestais; baldios).

Igualmente significativa da ruralidade da área raiana da Beira Interior é a estrutura do povoamento. As sedes de concelho são aglomerações modestas e mesmo antes do decréscimo 
demográfico dos últimos decénios cabiam-lhes valores relativamente discretos (quadro II): note-se que todas elas perderam população de 1940 a 1960 , mas sobretudo as do sul, com destaque para Idanha, tal como nos decénios seguintes, de aceleração das perdas nestas, de relativa estagnação do ritmo na de Sabugal mas de acentuada desaceleração na de Almeida.

\section{QUADRO II}

População das sedes de concelho e sua evolução

\begin{tabular}{|c|c|c|c|c|}
\hline & Almeida & Sabugal & Penamacor & Idanha \\
\hline $1981 \ldots .$. & $1434(1)$ & $1.897\left({ }^{2}\right)$ & 1985 & $2312\left(^{3}\right)$ \\
\hline 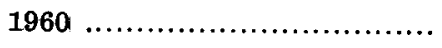 & 1492 & 2077 & 2477 & 4125 \\
\hline $1940 \ldots \ldots \ldots \ldots \ldots \ldots \ldots \ldots \ldots \ldots \ldots \ldots \ldots \ldots$ & 1691 & 2287 & 2855 & 5106 \\
\hline $1940-60(\%) \ldots$. & $-11,8$ & $-9,2$ & $-13,2$ & $-17,5$ \\
\hline $1960-81(\%) \ldots \ldots \ldots$ & $-3,9$ & $-8,7$ & $-19,9$ & $-44,0$ \\
\hline Pop. 1981/Pop. 1940 (\%) .... & 84,8 & 82,9 & 69,5 & 45,3 \\
\hline
\end{tabular}

(1) 2464 em Vilar Formoso; ( $\left.{ }^{2}\right) 1208$ no Souto; $\left({ }^{3}\right) 1505$ no Ladoeiro, 1348 na Zebreira e 1023 em Penha Garcia.

Ao nível das freguesias, a população dos aglomerados sedes das mesmas representa, por sua vez, parcelas ainda bastante diferentes das suas populações totais, tal como em 1960, antes da afirmação da tendência para a concentração demográfica e a simplificação da malha da repartição espacial da população (fig. 2). Aqueles valores traduzem diferentes tipos dominantes de povoamento, se bem que a pequenez de muitas freguesias da área de feição trasmontana acentue graficamente a sua concentração, obtendo-se valores semelhantes aos da Beira Baixa, onde predominam grandes aldeias e é percentualmente pouco significativa a dispersão em montes (Rosmaninhal) e quintas (Monsanto, Monfortinho e Penha Garcia).

Em 1981, os isolados, predominantemente do sexo masculino, eram contudo ainda mais comuns nos concelhos de Penamacor e Idanha; mais de metade da população residia em lugares de menos de $\mathbf{5 0 0}$ habitantes nos de Almeida e Sabugal e em lugares de 500 a 999 habitantes no de Penamacor, evidenciando diferenças significativas da estrutura do povoa- 


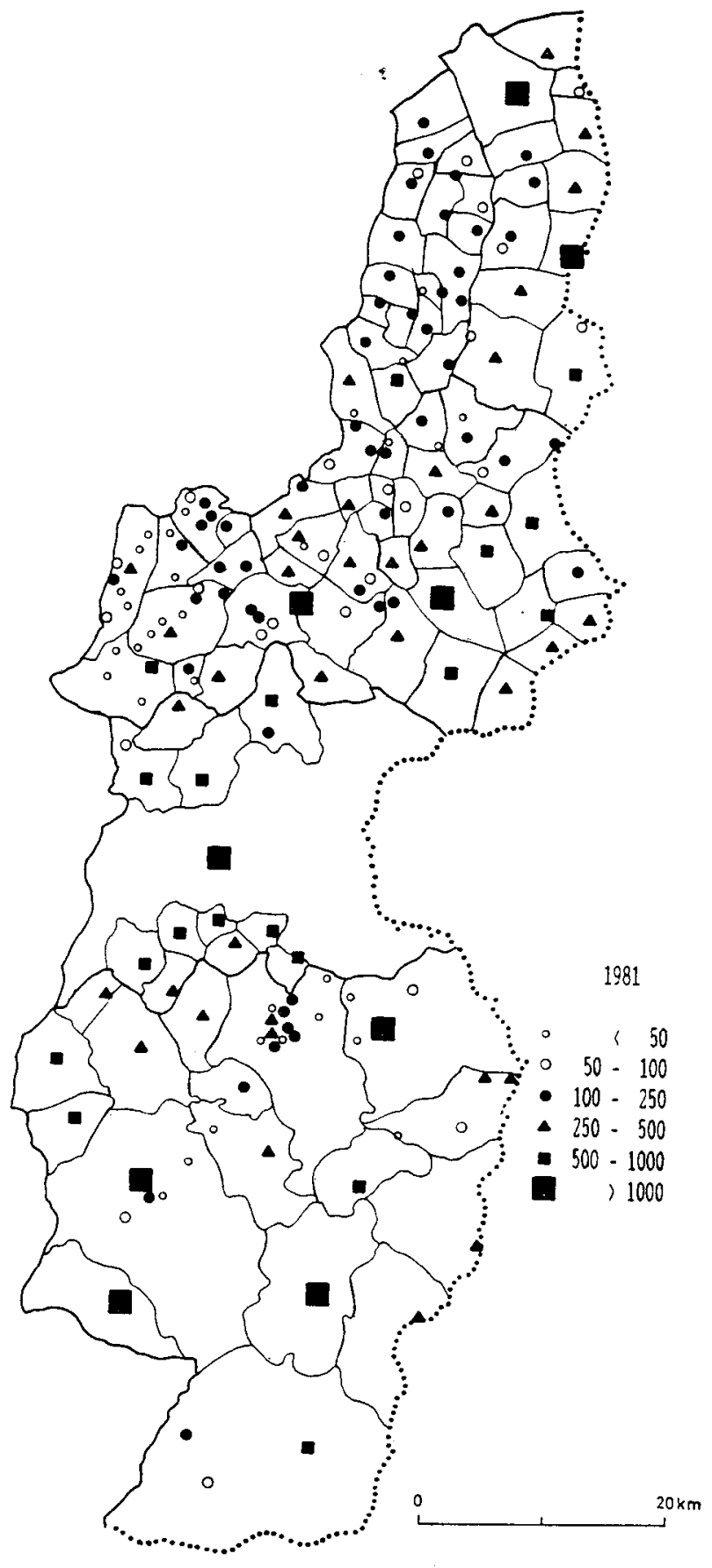

Fig. 2 - População residente, em 1981, em aldeias e lugares. 
mento, simplificada numa densa malha de pequenas aldeias a norte e combinando grandes aldeias, distantes entre si, pequenas aldeias, lugarejos e dispersão intercalar (montes e arraiais) a sul (quadro III) (fig. 3).

Considerando a dimensão demográfica das freguesias (fig. 4, quadro IV), destacam-se unidades administrativas muito pequenas, sobretudo no concelho de Almeida, onde mais de 1/4 tem menos de 150 habitantes e cerca de $2 / 3$ menos de 250 habitantes. Estes valores descem porém a $10 \%$ e $20 \%$, respectivamente, no de Sabugal, e quase se anulam no de Idanha, enquanto em Penamacor se não conta nenhuma freguesia destas dimensões. Com efeito, no concelho de Sabugal predominam as de 250 a 500 habitantes, seguidas pelas de 500 a 750 habitantes, e no de Penamacor estas e as do escalão 750 a 1000 habitantes, enquanto no de Idanha, a par das maiores frequências nestes escalões, figuram também as de 1000 habitantes e mais.

De notar que a concentração da população se acentua nas áreas com menor densidade demográfica, que em 1981 rondava os $20 \mathrm{hab} . / \mathrm{km}^{2}$ nos concelhos de norte mas descia a cerca de $11 \mathrm{hab} . / \mathrm{km}^{2}$ no de Idanha, Penamacor aproximando-se do primeiro conjunto. Dado que as dimensões espaciais e demográficas das freguesias se correspondem em grande medida, as densidades médias à sua escala não são muito contrastadas (fig. 5). De facto, tanto nas do concelho de Almeida como nas do de Idanha predominam valores inferiores a $15 \mathrm{hab} . / \mathrm{km}^{2}$, enquanto nas do de Sabugal se afirmam as densidades entre 15 e $25 \mathrm{hab} . / \mathrm{km}^{2}$; neste concelho estão bem representadas as de 25 a $35 \mathrm{hab} . / \mathrm{km}^{2}$ e mesmo as de 35 a $45 \mathrm{hab} . / \mathrm{km}^{2}$ (com frequência idêntica às de menos de $15 \mathrm{hab} . / \mathrm{km}^{2}$ ) (quadro $\mathrm{v}$ ). As freguesias com densidades superiores a $45 \mathrm{hab} . / \mathrm{km}^{2}$ são pouco numerosas: Vilar Formoso (181) no de Almeida; Quintas de S. Bartolomeu (81) e Sabugal (69) no de Sagugal; Aranhas (97), Salvador (101) e Aldeia do Bispo (157) no de Penamacor.

Fracas densidades populacionais, estruturas administrativas fragmentadas, dispersão da população por pequenas aldeias e lugarejos, sedes concelhias sem dimensão urbana, espaços incultos, florestados ou de utilização agrícola e pecuária bastante extensiva, eis um conjunto numeroso de traços da ruralidade da área raiana. A fronteira, todavia, não a separa 


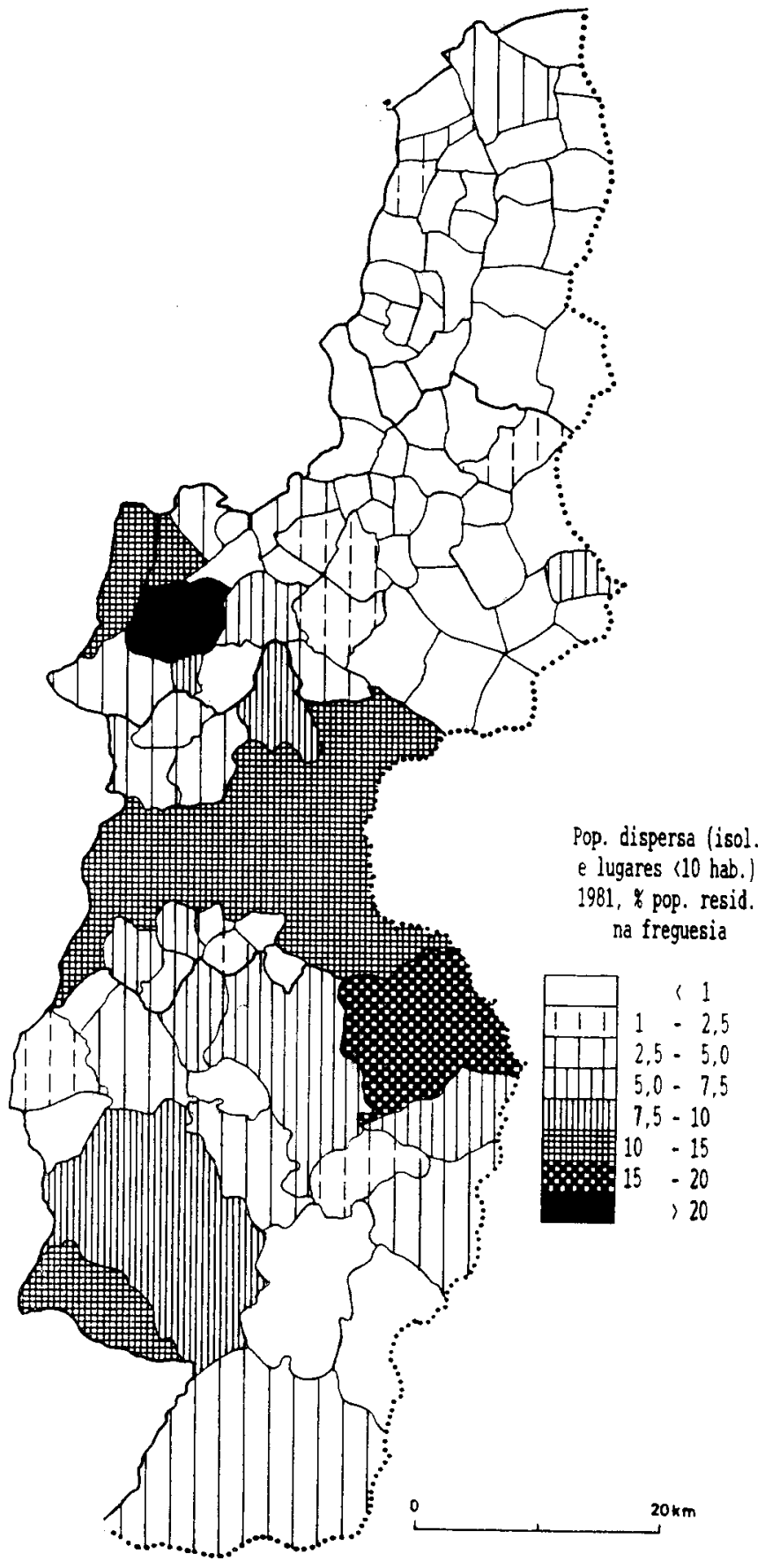

Fig. 3-População residente, em 1981, isolada e em lugares com menos de 10 habitantes. 


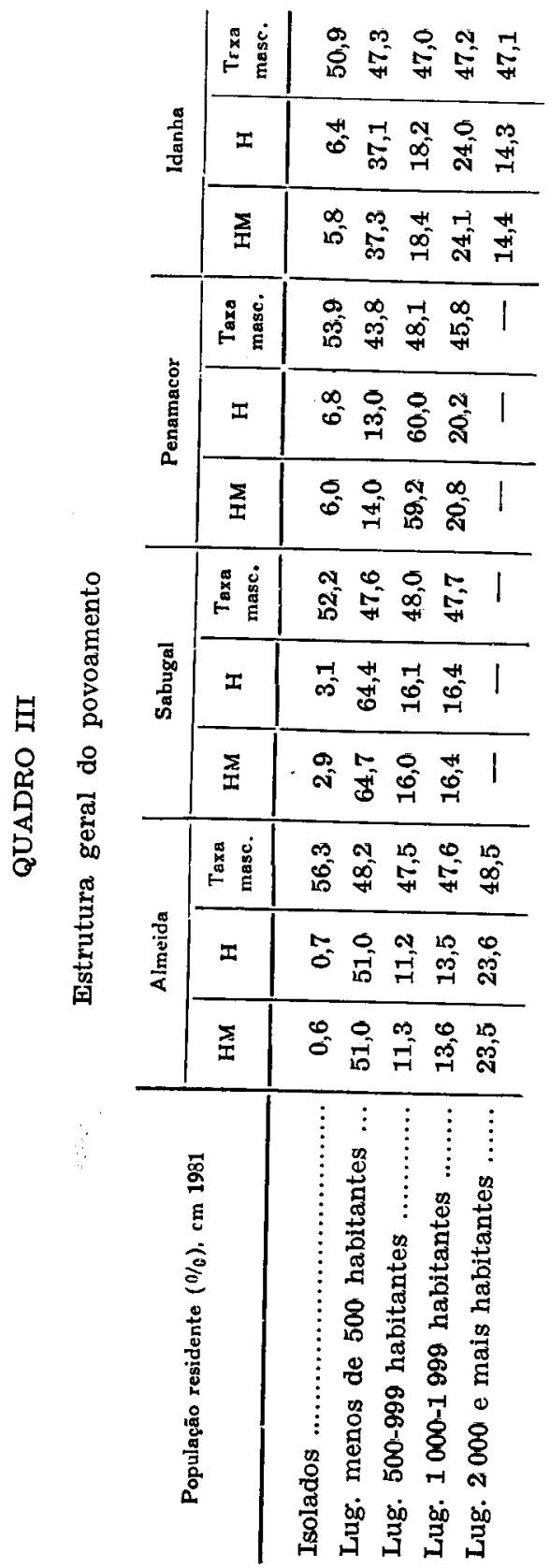




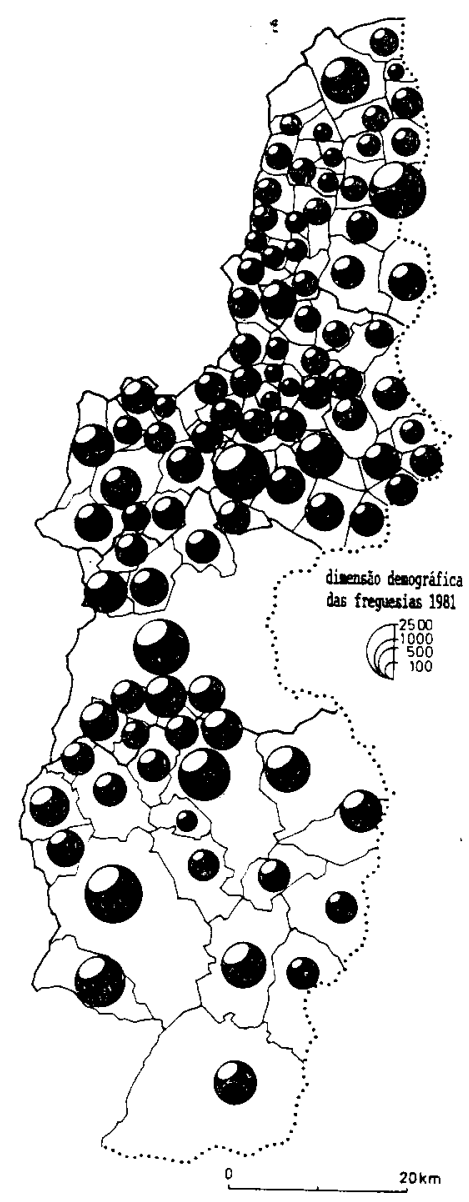

Fig. 4-Dimensão demográfica das freguesias, em 1981 (população residente).

de áreas muito diferentes: em Espanha, os municípios vizinhos (unidade entre o concelho e a freguesia, mas próxima desta em área e população) são também eles marcadamente rurais, mesmo se a maior concentração do povoamento permite - em áreas de menores densidades demográficas - a afirmação de aldeias-centro, com funções terciárias diversas e capazes de polarizar alguma procura dos residentes raianos de Portugal, sobretudo na região estremenha do norte (quadro vi). 


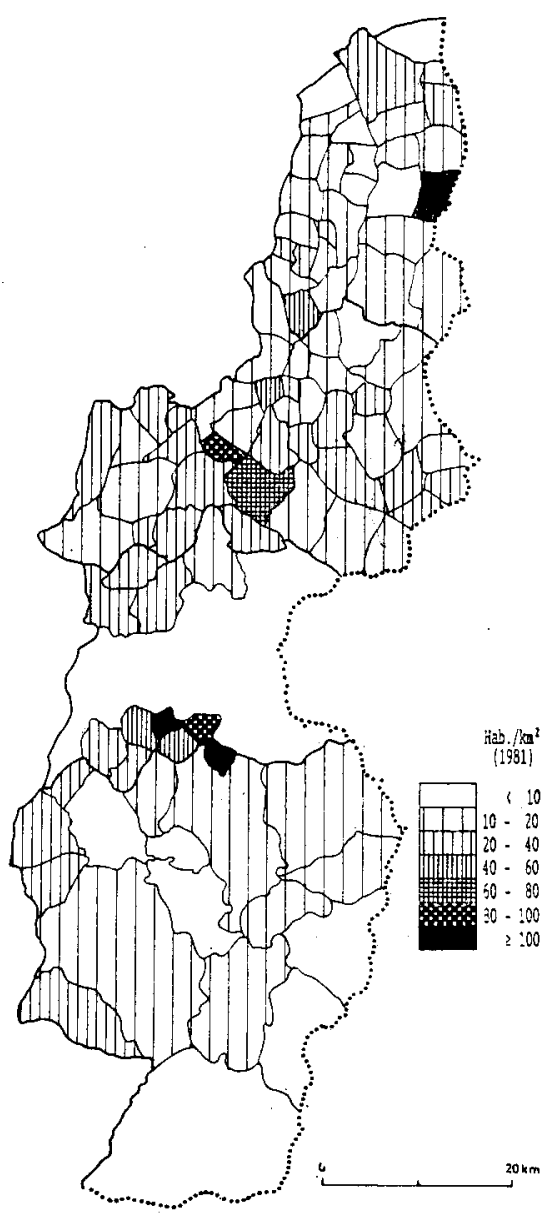

Fig. 5-Densidades demográficas, em 1981, por freguesias.

\section{Campos Predominantemente Agrícolas}

A população residente nestes concelhos em estudo, permanece fortemente ligada à agricultura, no seu sentido mais lato, mesmo quando desenvolve outras actividades, em termos profissionais ou como ocupação complementar, e dispõe de rendimentos predominante ou secundariamente com origem não agrícola. Indicam-no o peso da população agrícola familiar na população residente, o da população activa agrícola na 


\section{QUADRD IV}

Dimensão demográfica das freguesias, em 1981

\begin{tabular}{|c|c|c|c|c|c|c|c|c|}
\hline \multirow{2}{*}{$\begin{array}{c}\text { Número } \\
\text { do } \\
\text { habitantes }\end{array}$} & \multicolumn{2}{|c|}{ Almeida } & \multicolumn{2}{|c|}{ Sabugal } & \multicolumn{2}{|c|}{ Penamacor } & \multicolumn{2}{|c|}{ Idanha } \\
\hline & $\begin{array}{l}N .0 \text { de } \\
\text { freg. }\end{array}$ & $\%$ & $\begin{array}{l}\text { N.0 de } \\
\text { freg. }\end{array}$ & $\%$ & $\begin{array}{c}\text { N.0 de } \\
\text { freg. }\end{array}$ & $\%$ & $\begin{array}{l}N .0 \text { de } \\
\text { freg. }\end{array}$ & $\%$ \\
\hline$<150$ & 8 & 27,7 & 4 & 10,0 & 一 & - & 1 & 5,9 \\
\hline $150-250$ & 11 & 37,9 & 4 & 10,0 & - & - & - & - \\
\hline $250-500$ & 6 & 20,8 & 18 & 45,0 & 3 & 25,0 & 4 & 23,5 \\
\hline $500-750$ & 1 & 3,4 & 10 & 25,0 & 4 & 33,3 & 4 & 23,5 \\
\hline $750-1000$ & 1 & 3,4 & 2 & 5,0 & 4 & 33,3 & 2 & 11,8 \\
\hline $1000-1500$ & 1 & 3,4 & 1 & 2,5 & - & - & 3 & 17,6 \\
\hline $1500-2000$ & - & - & - & - & - & - & 2 & 11,8 \\
\hline $2000-3000$ & 1 & 3,4 & 1 & 2,5 & 1 & 8,4 & 1 & 5,9 \\
\hline Total & 29 & 100,0 & 40 & 100,0 & 12 & 100,0 & 17 & 100,0 \\
\hline
\end{tabular}

QUADRO V

Densidades demográficas das freguesias (1981)

\begin{tabular}{|c|c|c|c|c|c|c|c|c|}
\hline \multirow{2}{*}{$\begin{array}{l}\text { Densidades } \\
\left(\text { hab./km }{ }^{2}\right)\end{array}$} & \multicolumn{2}{|c|}{ Almeida } & \multicolumn{2}{|c|}{ Sabugal } & \multicolumn{2}{|c|}{ Penamacor } & \multicolumn{2}{|c|}{ Idanha } \\
\hline & $\begin{array}{l}\text { N.o de } \\
\text { freg. }\end{array}$ & $\%$ & $\begin{array}{l}\mathrm{N} .0 \text { de } \\
\text { freg. }\end{array}$ & $\%$ & $\begin{array}{l}\mathrm{N} \cdot{ }^{\circ} \text { de } \\
\text { freg. }\end{array}$ & $\%$ & $\begin{array}{l}\mathrm{N} . \text { do } \\
\text { freg. }\end{array}$ & $\%$ \\
\hline$<15$ & 16 & 55,3 & 4 & 10,0 & 2 & 16,7 & 11 & 64,7 \\
\hline $15-25$ & 9 & 31,0 & 24 & 60,0 & 3 & 25,0 & 3 & 17,6 \\
\hline 25-35 & 2 & 6,9 & 6 & 15,0 & 一 & - & 2 & 11,8 \\
\hline $35-45$ & $\mathbf{1}$ & 3,4 & 4 & 10,0 & 4 & 33,3 & 1 & 5,9 \\
\hline$\geqslant 45$ & 1 & 3,4 & 2 & 5,0 & 3 & 25,0 & 一 & - \\
\hline Total & 29 & 100,0 & 40 & $100 ; 0$ & 12 & 100,0 & 17 & 100,0 \\
\hline
\end{tabular}

população activa total e os da população activa nos diferentes ramos de actividade integrada em famílias agrícolas cultivando explorações da região.

A população agrícola familiar, computada em 1979 pelo Recenseamento Agrícola do Continente, representava, com efeito, no concelho de Almeida, 65,1\% da população residente, segundo o Recenseamento da População de 1981, no de Sabugal $71,6 \%$ e no de Penamacor 60,5\%; no de Idanha descia porém a $43,2 \%$, mas ainda se contavam neste muitos jornaleiros sem 


\begin{tabular}{|c|c|c|c|}
\hline & $\begin{array}{c}\mathrm{N} \cdot{ }^{0} \text { de } \\
\text { habitantes }\end{array}$ & $\mathrm{Hab} \cdot / \mathrm{km}^{2}$ & $\begin{array}{c}\text { Regressão } \\
\text { 1950-81 (0\%) }\end{array}$ \\
\hline Valverde del Fresno ................... & 2466 & 13,1 & $-44,6$ \\
\hline Cilleros $\ldots \ldots \ldots \ldots \ldots \ldots \ldots \ldots \ldots \ldots \ldots$ & 2491 & 12,2 & $-40,2$ \\
\hline Zarza la Maior ... & 1958 & 11,7 & $-56,8$ \\
\hline Pedras Albas ...... & 324 & 72,0 & $-78,0$ \\
\hline Alcântara ................ & 2317 & 4,3 & $-44,2$ \\
\hline
\end{tabular}

(') E a norte, Aldeia del Obispo 537, La Alameda de Gardon 328, La Alamedilha 346, La Alberguera 380, Casillas de Flores 351, Navasfrias 940; etc.

terra e sem explorações, nem mesmo minúsculas e de renda ou parceria (2831 explorações, 441 com trabalhadores eventuais e $183 \mathrm{com}$ trabalhadores permanentes, em 1979; 1780 trabalhadores agrícolas de conta doutrem em 1981, no total de 2475).

$\bar{A}$ escala das freguesias (fig. 6), verificamos valores percentuais particularmente altos na Beira Trasmontana, com excepção das freguesias compreendendo as sedes de concelho (Almeida e mais ainda Sabugal: 28,7\%) ou sob a sua influência; de Vilar Formoso, que regista o valor mais baixo $(5,7 \%)$ pelo peso do sector terciário desenvolvido em função da passagem; de outras ao longo da fronteira (Nave do Haver, Lageosa, Foios e Vale de Espinho, bem como do Souto, vizinha das últimas), todas fortemente marcadas, directa ou indirectamente, pela sua posição (economias subterrâneas; emigração legal e clandestina; procura de bens e serviços em função do poder de compra da população; aforro e iniciativas empresariais diversas).

$\mathrm{Na}$ Beira Baixa a população agrícola familiar representa percentagens da população residente bem contrastantes com as da região a norte, já que muito inferiores, não apenas nas freguesias mais urbanas (Penamacor e Idanha-a-Nova: 11,1 \%), nas mais turísticas (Monfortinho 30,4\%) e nas dotadas de serviços de fronteira (Segura), mas em muitas outras, traduzindo sobretudo a presença de população rural e do sector 


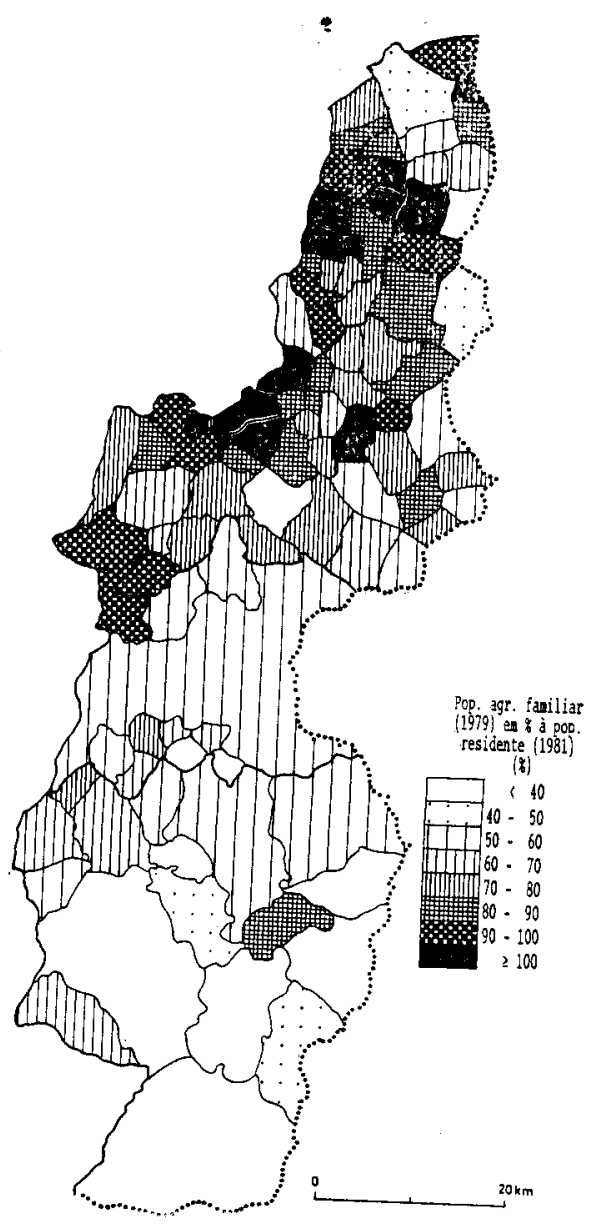

Fig. 6-População agrícola familiar recenseada em 1979, em percentagem da população residente em 1981, por freguesias.

primário desligada da posse e da condução de explorações familiares (Idanha-a-Velha 14\%; Rosmaninhal 20,5\%; Zebreira 24,5\% e Salvaterra do Extremo $34,2 \%$ ).

A repartição da população activa, em 1981, pelos principais ramos de actividade, a nível concelhio (quadro vin), traduz de igual modo a predominância da agricultura e silvicultura em termos de emprego: superior a $50 \%$ em todos os concelhos, 


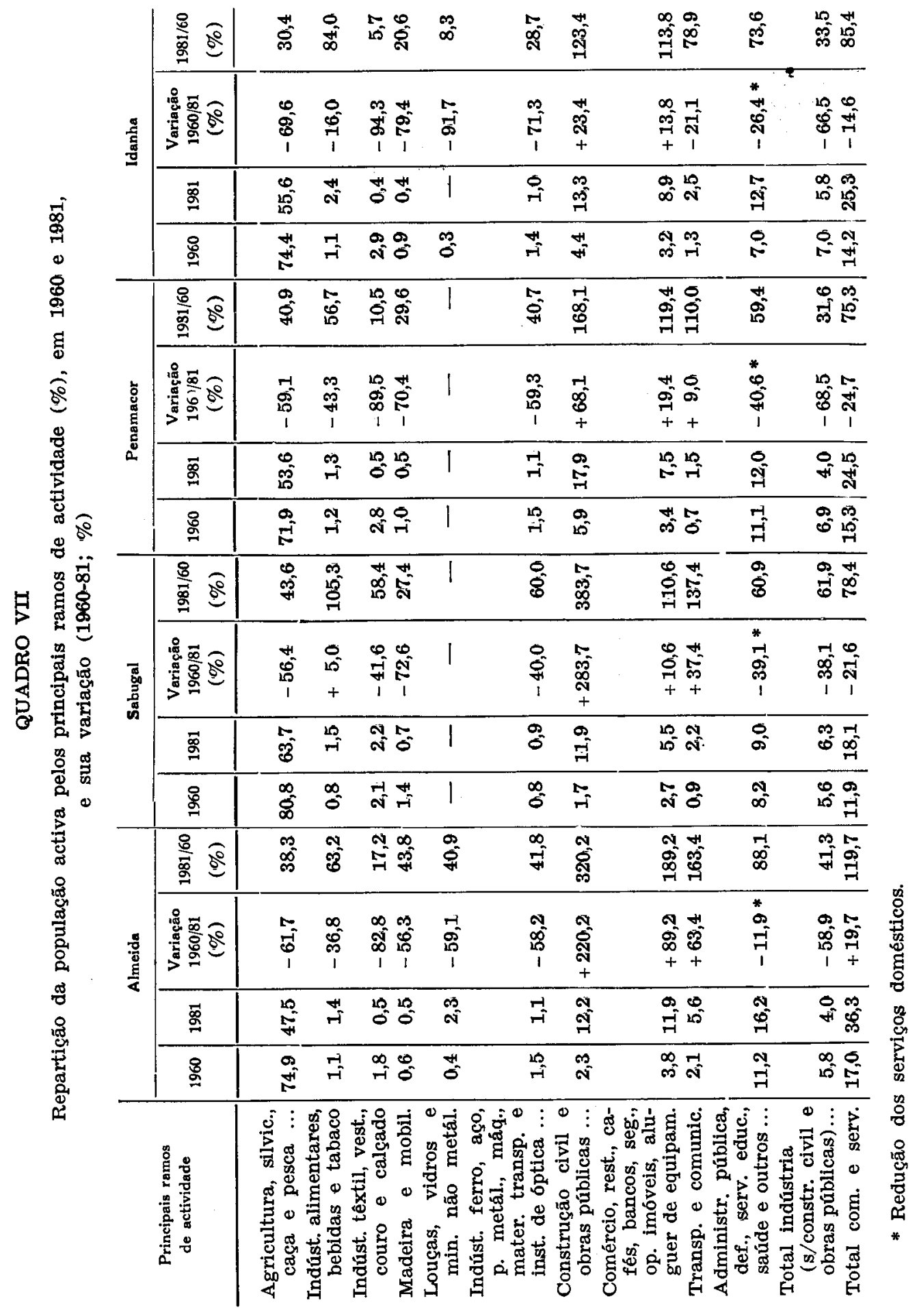


salvo no de Almeida, onde descè a 47,5 \%, em favor do terciário, particularmente do comércio, restaurantes, cafés, bancos e seguros, pelo equipamento não tanto da sede do concelho mas principalmente de Vilar Formoso. $O$ confronto com os valores percentuais de 1960 evidencia, naturalmente, redução do significado da agricultura, que então ainda ocupava mais de $70 \%$ da população activa, bem como o quase apagar da indústria, e inversamente a explosão da construção civil.

No geral, a população activa acompanhou a diminuição da população total, pelo que a de 1981 representava parcelas modestas da de 1960: 60,4 \% no concelho de Almeida, 55,4\% no de Sabugal, 54,9 \% no de Penamacor e 40,5 \% no de Idanha. Por ramos, no de Almeida todas as actividades industriais viram os seus efectivos diminuirem mais do que os do concelho, com excepção do agro-alimentar e das bebidas, mas a agricultura perdeu mais do que todos eles, exceptuando o conjunto têxtil, vestuário e calçado. A evolução foi semelhante no concelho de Sabugal, onde todavia a agricultura foi menos afectada e onde se expandiu o emprego no ramo agro-alimentar. No concelho de Penamacor a indústria perdeu mais intensamente empregos do que a própria agricultura, enquanto no de Idanha, embora ambas tenham sido bastante atingidas, a população activa na agricultura em 1981 representava apenas $30 \%$ da de 1960. Aliás, este concelho também registou acréscimos mais modestos no emprego na construção civil $(23,4 \%)$, seguido de perto por Penamacor $(68 \%)$, enquanto nos restantes os valores mais do que triplicaram ao longo dos anos 60 e 70 .

A escala das freguesias e para 1981, apenas dispomos de informação acerca da população activa no sector primário, mas esta identificava-se quase totalmente, em toda a região, com a da agricultura e silvicultura, já que as indústrias extractivas somente empregavam algumas dezenas de trabalhadores no concelho de Sabugal (28, mas 1 no de Idanha, 1 no de Almeida e nenhum no de Penamacor). Aquela representava percentagens da população residente com profissão no geral elevadas (fig. 7) : de novo, os valores mais baixos sublinhavam as que compreendem as sedes de concelho (Almeida 21,5\%, Sabugal 22,1\%, Penamacor $35 \%$ e Idanha 38\%), para além de Vilar Formoso $(4,7 \%)$, onde já era particularmente expres- 


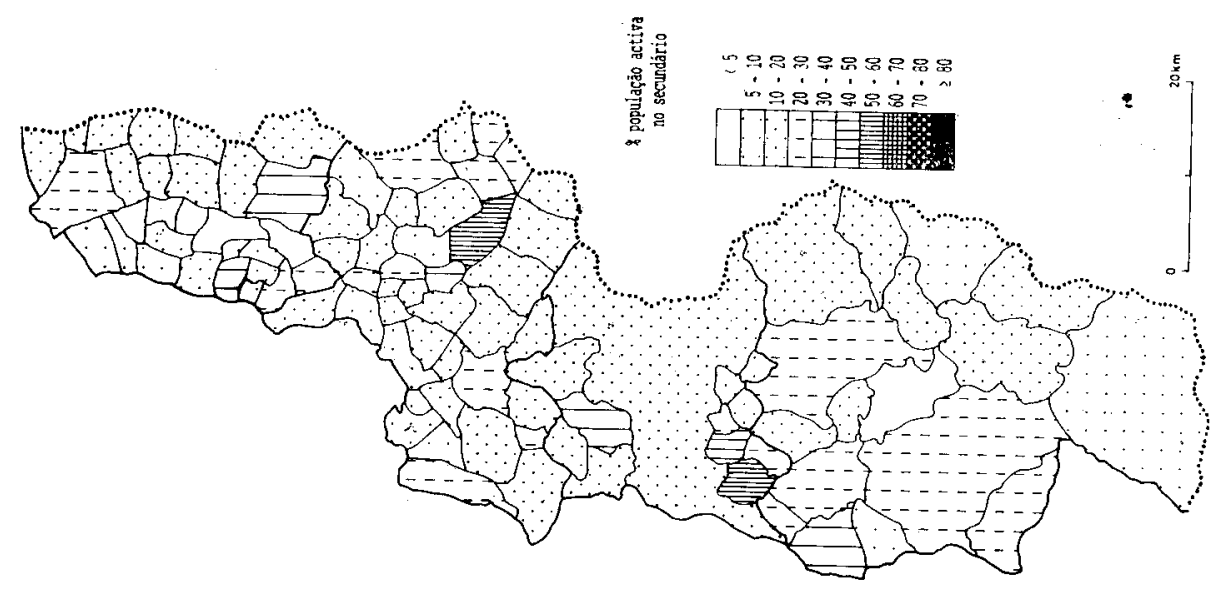

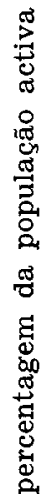
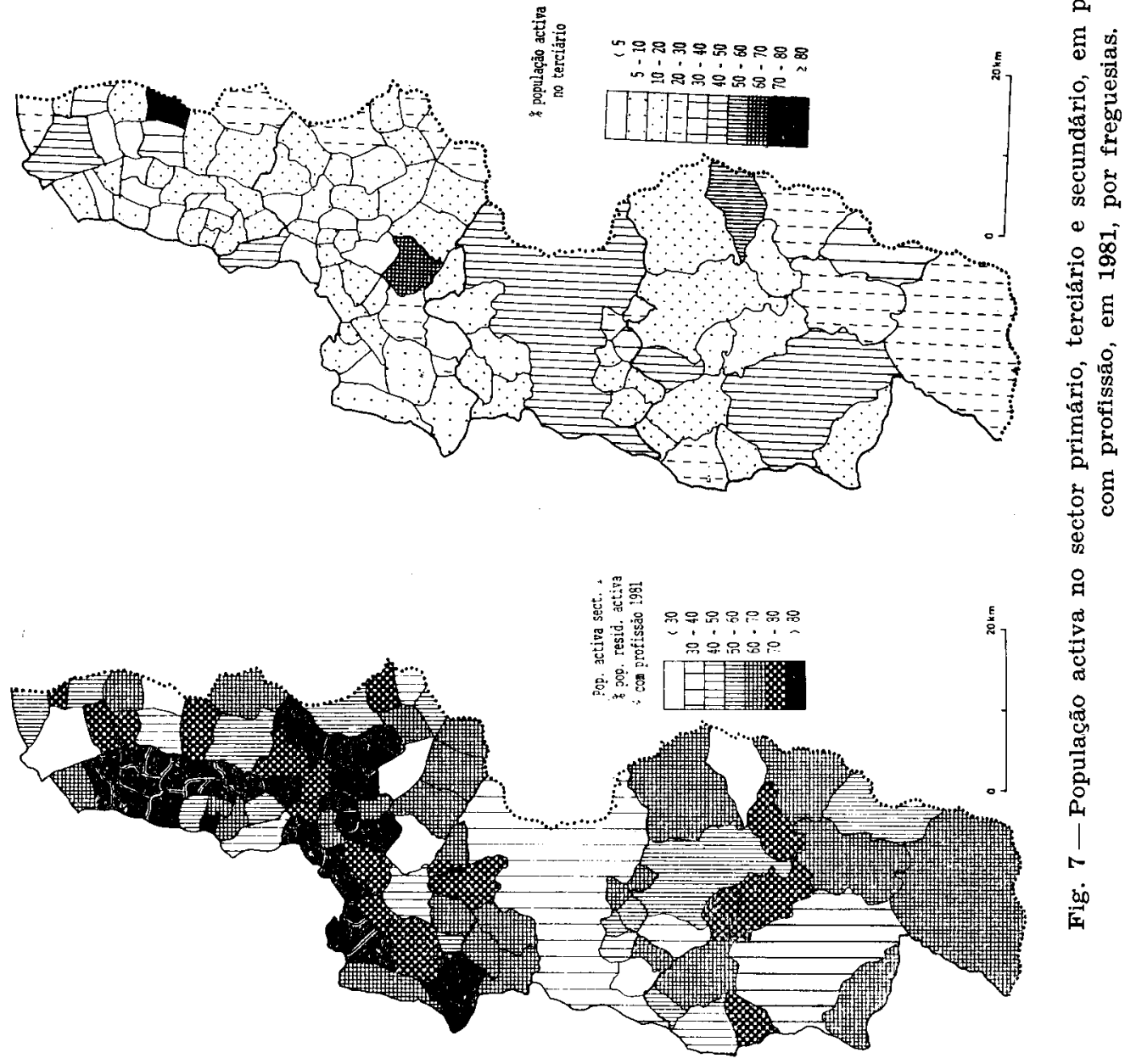
sivo o peso do sector terciário $(82,1 \%)$, de natureza social $(33 \%)$ e sobretudo relativo a actividades económicas $(49,1 \%)$, em ligação com a passagem da fronteira (fig. 7). Valores baixos ocorriam também na freguesia de Monfortinho (23\%), com $59 \%$ dos activos no terciário (Termas e seu equipamento), sendo 45,6\% nos ramos relativos a actividades económicas; e na do Souto, onde cede lugar ao emprego no secundário $(52,6 \%)$ (fig. 7) ; na freguesia de Castelo Bom, as actividades primárias $(45,3 \%)$ são secundadas de perto pelas terciárias, pela proximidade de Vilar Formoso, onde muitos trabalham, tal como na de Malpartida (56,6\% e 25,8\% respectivamente, contra $\mathbf{1 7 , 7} \%$ no secundário), provavelmente pelo emprego na vila de Almeida, hipótese que também retemos para Vale da Mula (52,2\% no primário e $31,3 \%$ no terciário). Várias freguesias dos concelhos de Sabugal, Penamacor e Idanha apresentam percentagens de população activa no sector primário entre 40 e $60 \%$ e repartição semelhante da restante pelos sectores secundário e terciário (Aldeia do Bispo, Aldeia da Ponte, Aldeia de Santo António, Lageosa, Moita, Aldeia de Santa Margarida) ou peso destacado do emprego no secundário (Águas $42 \%$; Aldeia do Bispo 29,1\%; Pedrógão 53,2\%; Monsanto 28\%; São Miguel da Acha 38,4\%) e no terciário (Cerdeira 44,3\%, Aldeia de João Pires 30,1\%, Medelim $42 \%$ e Segura 34,4\%).

Se considerarmos a relação população activa no sector terciário/população residente nas freguesias com maior número de empregos no terciário (Anexo II), verificamos todavia que os serviços são sempre pouco densos, até nas que compreendem as sedes de concelho: 13 para cada 100 na de Idanha, 16 nas de Almeida e Penamacor (tal como na de Monfortinho) e 20 na de Sabugal (e em Cerdeira); apenas na de Vilar Formoso este índice alcança 27. Por outro lado, constatamos que os serviços de natureza social cedem lugar aos de apoio às actividades económicas em freguesias tão díspares como Vilar Formoso, Souto, Benquerença, Pedrógão, Ladoeiro, Medelim, Monfortinho, Monsanto, Penha Garcia e São Miguel da Acha. Mesmo em freguesias com sede de concelho se encontram percentagens de emprego em serviços de natureza social relativamente pouco elevadas: $54 \%$ na de Sabugal, 59,7 $\%$ na de Penamacor e 60,4\% na de Idanha, contra 65,8 \% na de Almeida. 
Os valores da população activa na agricultura e silviculțura (por concelhos) e no sector primário (freguesias) apenas indicam por defeito o peso da população que realmente participa na actividade agrícola. De facto, nem todos os que trabalham neste sector se declararam activos com profissão no mesmo, quando do Recenseamento de 1981: o confronto da população então identificada como activa agrícola ou no sector primário com a população agrícola familiar que em 1979, quando do RAC, declarou trabalhar nas suas explorações (fig. 8) permite verificar que aquela representava percentagens modestas desta, salvo nalgumas freguesias da Beira Baixa onde tem maior peso a profissão no sector primário na condição de trabalhador por conta doutrem, permanente ou mesmo eventual, e consequentemente é maior a consciência da sua situação profissional.

Por último, consideremos como indicador do carácter rural destes espaços a percentagem de população activa nos grandes sectores de actividade que faz parte de agregados familiares agrícolas (quadro viII), apenas à escala dos concelhos já que se não dispõe de valores operativos para as freguesias. Os diferentes sectores são desigualmente penetrados por trabalhadores membros de famílias agrícolas, em busca de rendimentos e salários: valores percentuais particularmente altos ocorrem na construção civil de Sabugal e Penamacor, bem como no comércio e na hotelaria e restauração e mais ainda nas «outras actividades remuneradas», de natureza terciária, onde rondam ou ultrapassam $100 \%$, sugerindo em parte actividades terciárias ocasionais, irregulares, de ocupação ređuzida, que não justifica a sua integração como população activa nas mesmas. De notar também que muitos deles são pluriactivos, inclusive entre os que trabalham nas actividades terciárias.

Separemos os mercados de trabalho masculino e feminino (quadros IX e $\mathbf{x}$ ): no primeiro confirmam-se os dados globais, com atenuação dos valores correspondentes a «outras actividades remuneradas» (ainda superiores a $100 \%$ nos concelhos de Penamacor e Idanha), e acentua-se a pluriactividade no geral, e particularmente no comércio e hotelaria e nas «outras actividades remuneradas»; no feminino, afirma-se a penetração no mercado de trabalho agrícola nos concelhos de Almeida e Penamacor (vindimas? apanha da azeitona?), 


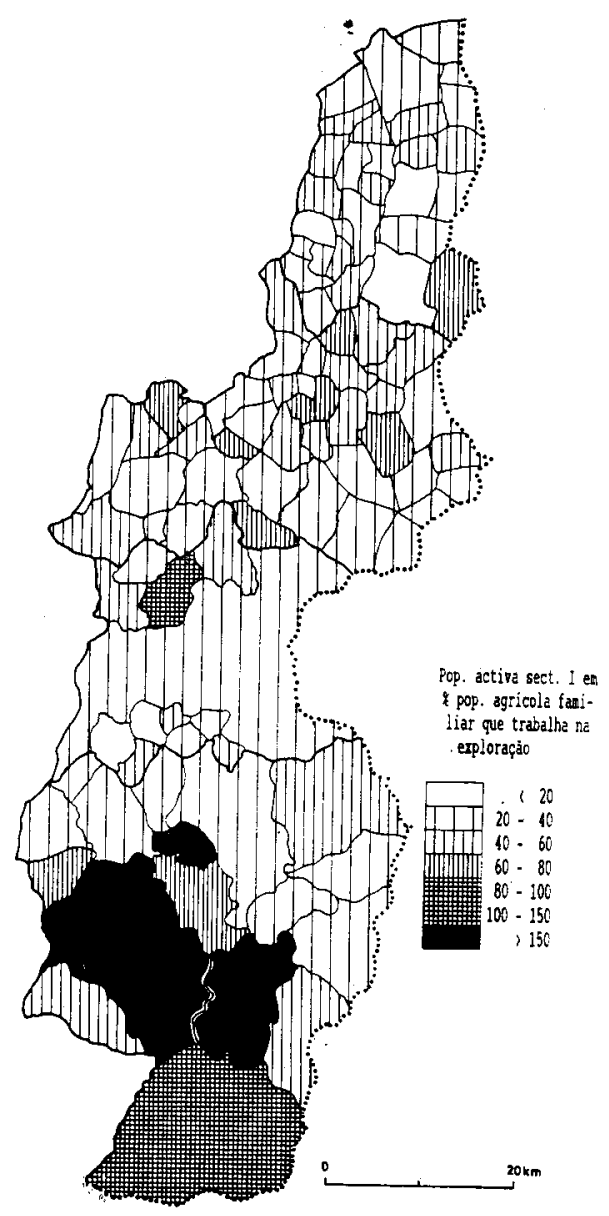

Fig. 8-População activa no sector primário (1981), em percentagem da população agrícola familiar que trabalha nas suas explorações (1979).

na indústria de Penamacor, de efectivos muito modestos, no comércio e hotelaria de todos os concelhos com excepcaão de Penamacor e nas «outras actividades» nos de Almeida e Penamacor. A pluriactividade agrícola tem, contudo, menor peso no mercado feminino de trabalhadores agrícolas por conta doutrem que no masculino, bem como a pluriatividade feminina na indústria (cerca de metade dos valores da masculina, se 


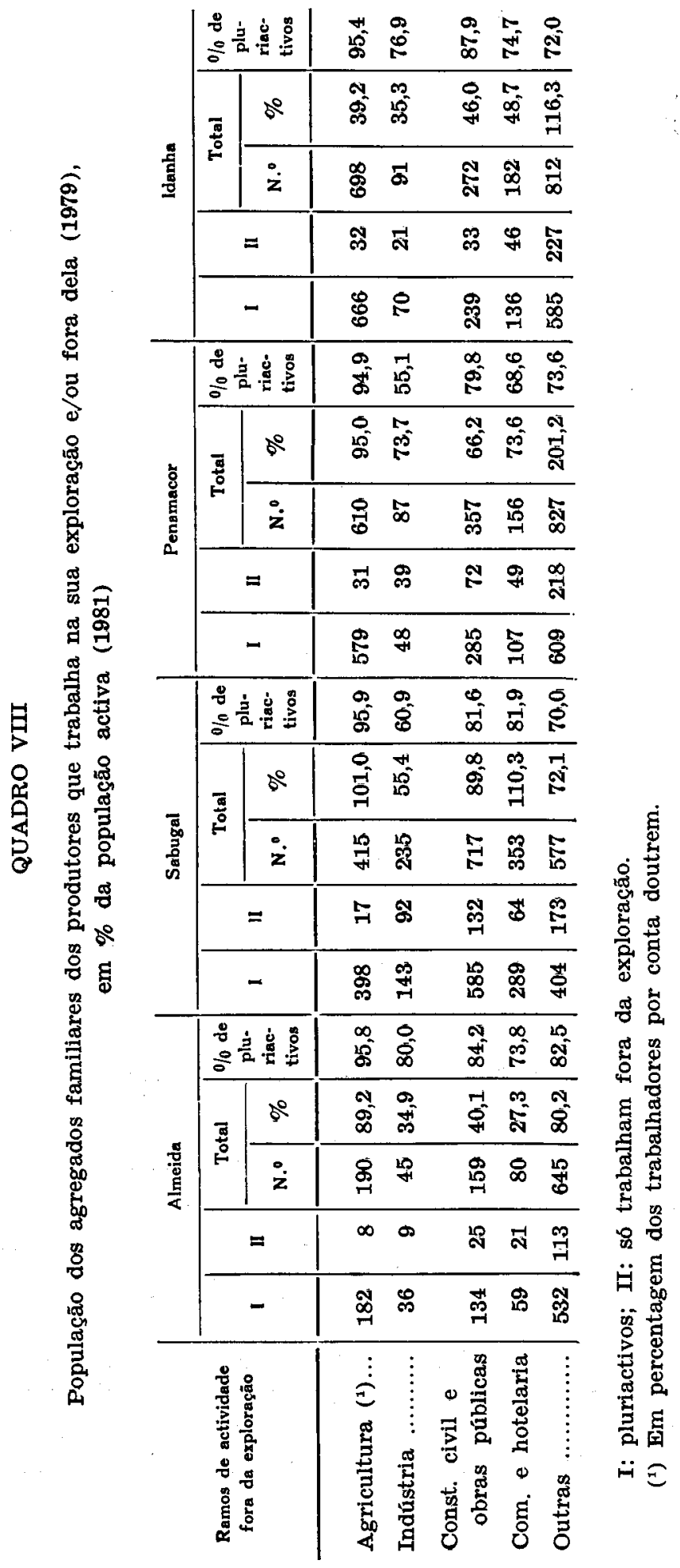




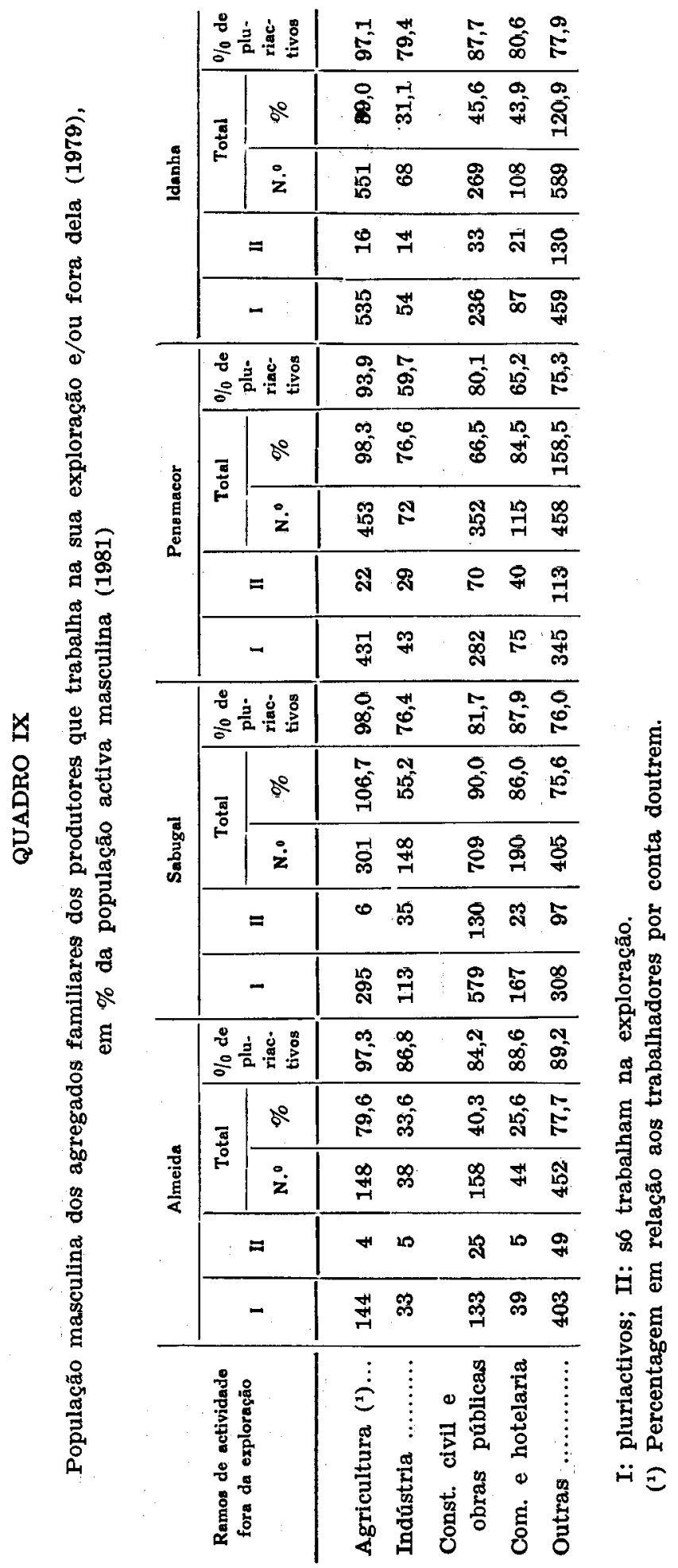




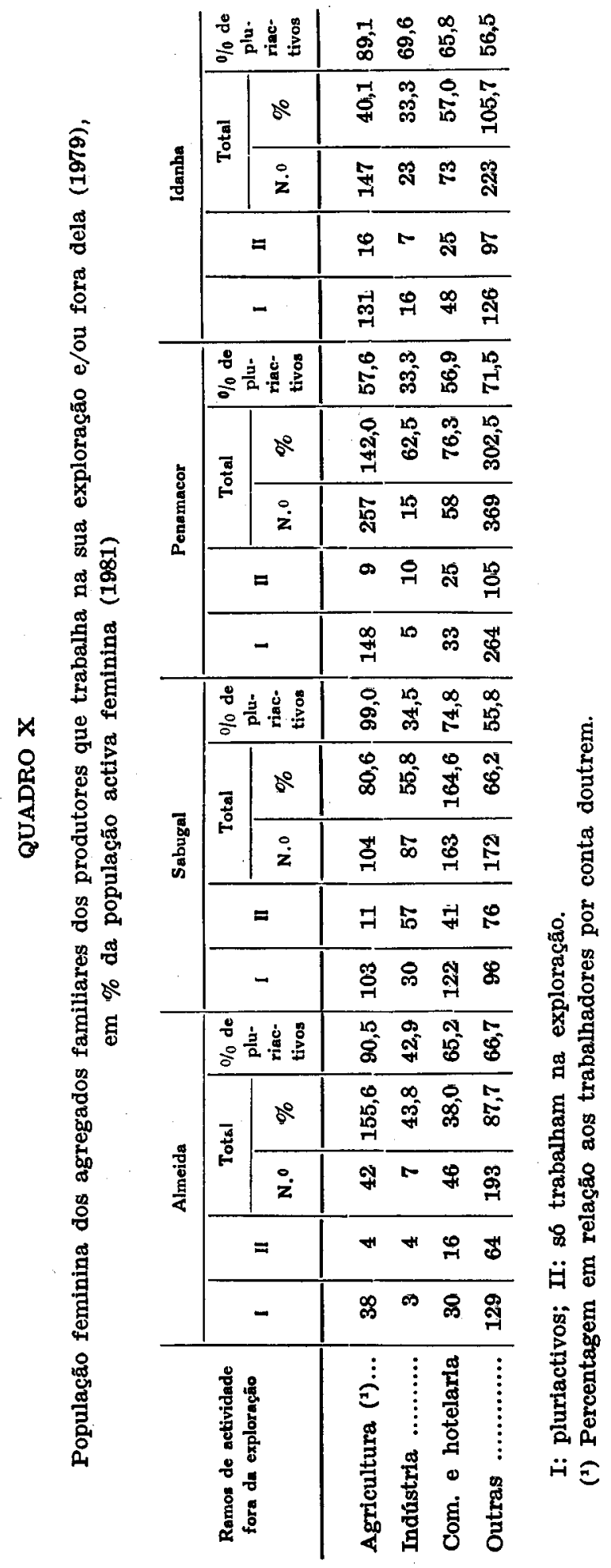


exceptuarmos Idanha); no comércio e hotelaria é também menos significativa, do mesmo modo que nas «outras actividades remuneradas». Ou seja, as famílias agrícolas penetram fortemente os diferentes segmentos do mercado de trabalho masculino e feminino, os seus elementos femininos participam particularmente no agrícola e no terciário, a tempo parcial em muitos casos e desprezando o trabalho na exploração familiar mais frequentemente do que os masculinos, pois as parcelas de pluriactivos situam-se claramente abaixo das verificadas entre aqueles.

Esta penetração de origem agrícola dos vários campos de trabalho relaciona-se com a evolução do emprego nos diferentes ramos de actividade e a condição na profissão dominante em cada ramo. No período 1960-81 observou-se, de facto, expansão no emprego feminino agrícola em todos os concelhos e no do comércio e serviços nos de Almeida e Idanha; paralelamente, houve expansão no emprego masculino na construção civil em todos os concelhos e no comércio e serviços no de Almeida. A tendência para a feminização do emprego foi acentuada entre a população activa agrícola de todos os concelhos, a do comércio e serviços no concelho de Idanha e a da indústria no de Sabugal. Note-se ainda que só nos concelhos da Beira Baixa é bem significativa a condição dependente da população activa agrícola, designadamente no de Idanha, situação que se repete em todos os concelhos entre os trabalhadores da construção civil, em oposição aos do comércio a retalho, que trabalham predominantemente de conta própria.

\section{Campos de há Muito Repulsivos}

A evolução da população residente (fig. 9) caracteriza-se, em traços gerais, pela ocorrência de máximos em todos os concelhos em 1950. Estes sucedem-se a quebras dos ritmos ascendentes da segunda metade do século XIX e dos primeiros decénios deste, as quais se verificaram nos períodos 1911-20 e 1920-30 nos concelhos de Sabugal e Almeida, no primeiro no de Idanha e pouparam o de Penamacor. Aqueles máximos foram mais marcados nos concelhos mais populosos (Sabugal e Idanha), embora não necessariamente de maiores densidades 

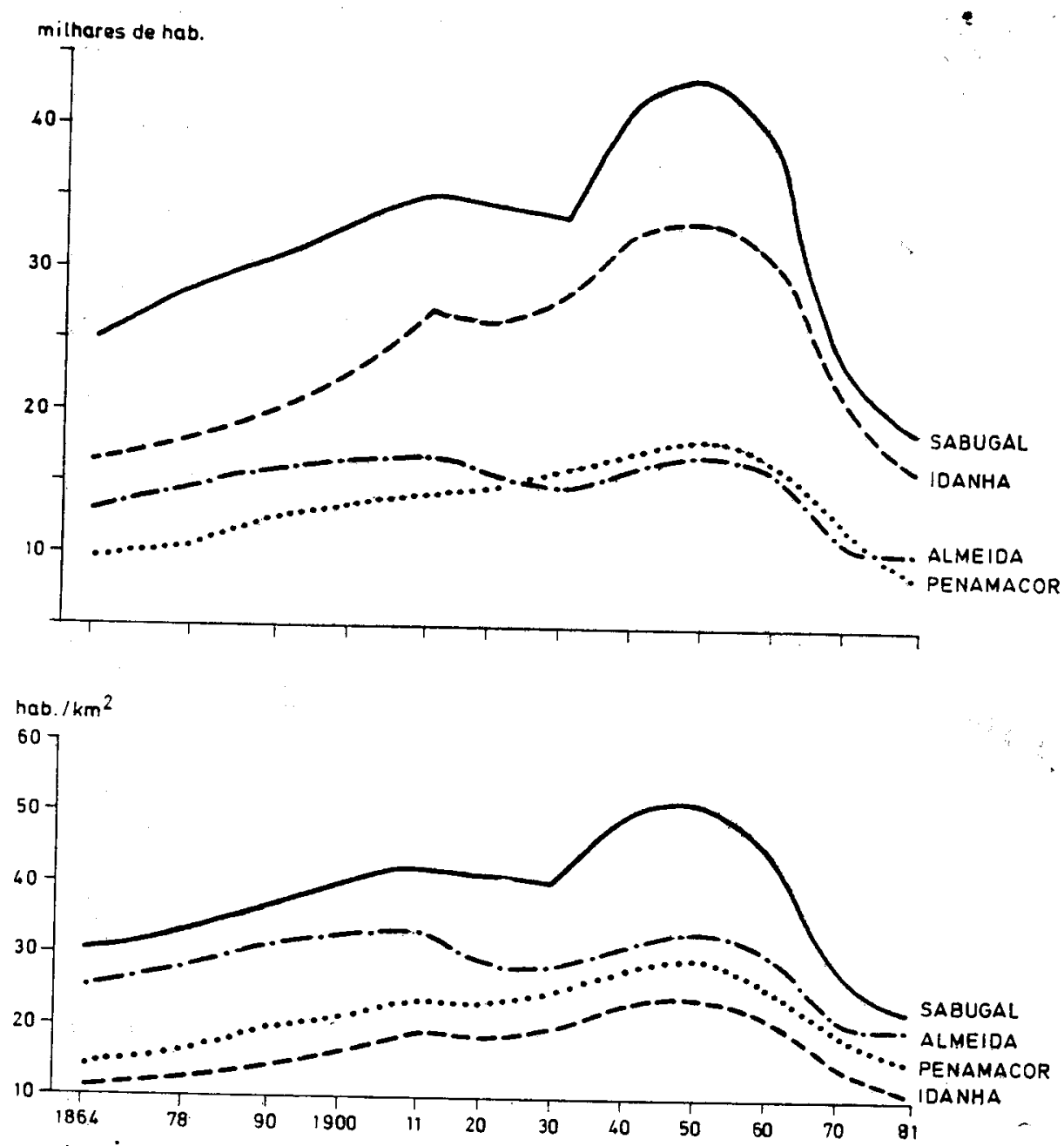

ots. pimporses

Fig. 9-Evolução da população residente e da densidade demográfica (1864 a 1981), por concelhos.

populacionais, já que Almeida registava então volumes demográficos da ordem dos do início do século. A partir de 1950 todos os concelhos perderam população: o ritmo das perdas atenuou-se todavia durante os anos 70, quando os volumes demográficos se tornaram inferiores aos de cem anos antes; só no concelho de Almeida a evolução descendente-deu então 
lugar a ligeiro aumento, permikindo a aproximação da sua densidade populacional da do concelho de Sabugal, de que muito se distanciara desde 1900 mas sobretudo no periodo 1930-1960.

Descendo a análise à escala das freguesias, verificamos alguma diferenciação significativa dos espaços concelhios. Muitas freguesias do concelho de Almeida registaram os seus máximos demográficos até aos anos 20, muitas outras do concelho de Sabugal em 1940, enquanto nas do concelho de Idanha os máximos ocorreram frequentemente entre 1920 e 1940 (fig. 10C). As variações intercensitárias correspondem a acréscimos ou a estagnações de sinal positivo, no período 1878-1900 (fig. 10A), sendo as últimas mais frequentes nos concelhos da Beira Trasmontana; a diminuições e estagnações de sinal negativo nestes mesmos concelhos no período 1900-1920, sendo as primeiras particularmente importantes nos sectores interior e norte do concelho de Almeida, enquanto nas freguesias dos concelhos de Penamacor e Idanha se verificavam estagnações de sinal positivo e acréscimos demográficos; no período 1920-1940 (fig. 10B) houve aumentos generalizados, se bem que relativamente moderados em quase todas as freguesias do concelho de Almeida e na maior parte das de Sabugal e Penamacor, as excepções ajustando-se a áreas com potencialidades para sistemas agrícolas mais intensivos e estruturas fundiárias fragmentadas, enquanto no de Idanha beneficiaram provavelmente das novas arroteias com vista à cultura do trigo; nos decénios seguintes (1940-1960) a resultante converteu-se em decréscimos e estagnações de população, tendo contudo as perdas maior continuidade espacial no concelho de Idanha, onde as principais excepções se devem ao desenvolvimento do termalismo em Monfortinho e do regadio no Ladoeiro; finalmente, no período 1960-1980 (fig. 10C) acentuaram-se e generalizaram-se espacialmente os decréscimos de população, sendo excepção apenas as freguesias de Almeida e Vilar Formoso.

Esta evolução demográfica traduz a dominante repulsiva destes espaços raianos, inclusive das suas freguesias urbanas, que alimentaram importantes migrações internas e fluxos de emigração, rão compensados pelos saldos fisiológicos, nem por movimentos de atracção. De facto, em 1960 (quadro xI), 


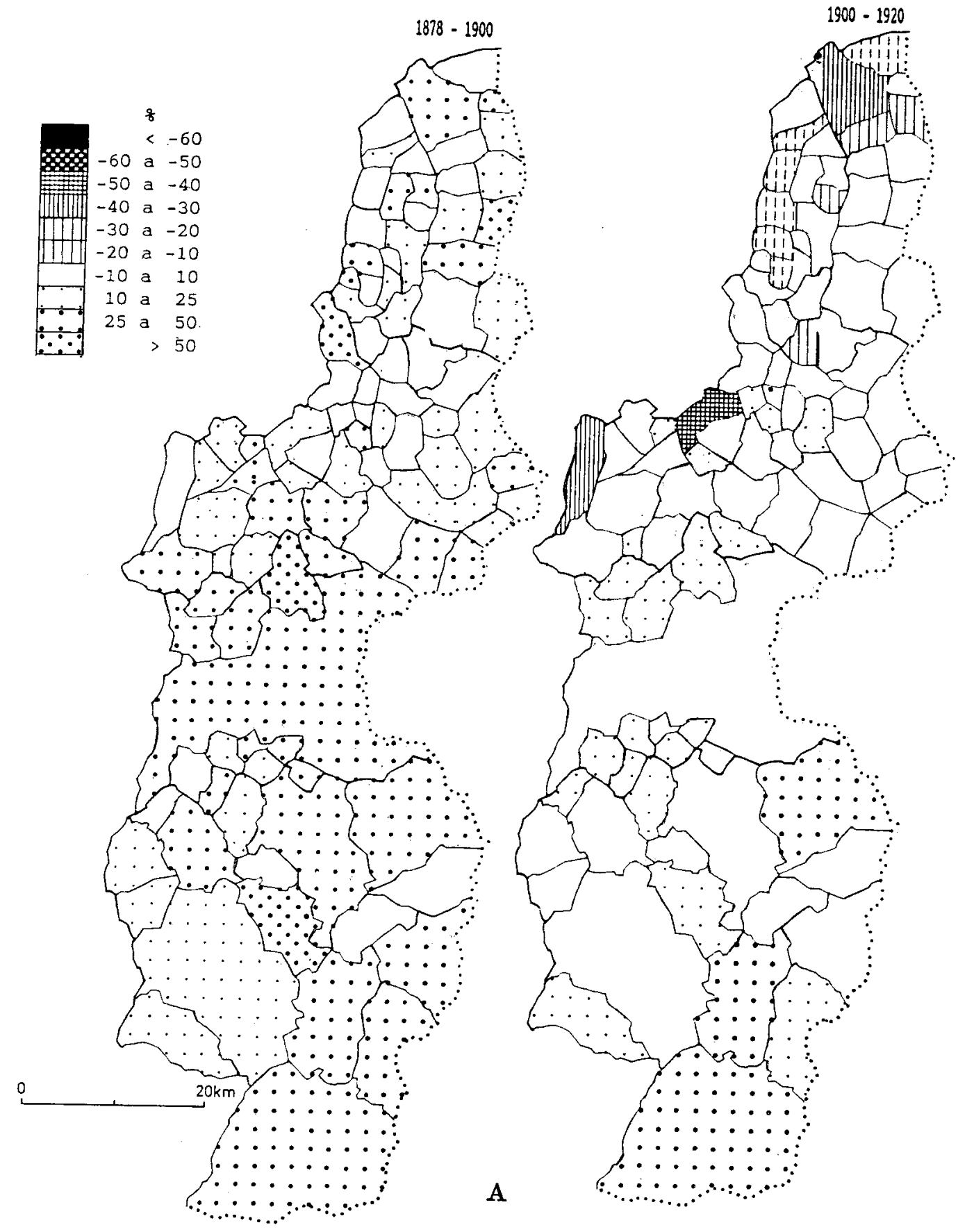

Fig. 10A - Variação da população residente, por freguesias, nos períodos 1878-1900 e 1900-1920. 


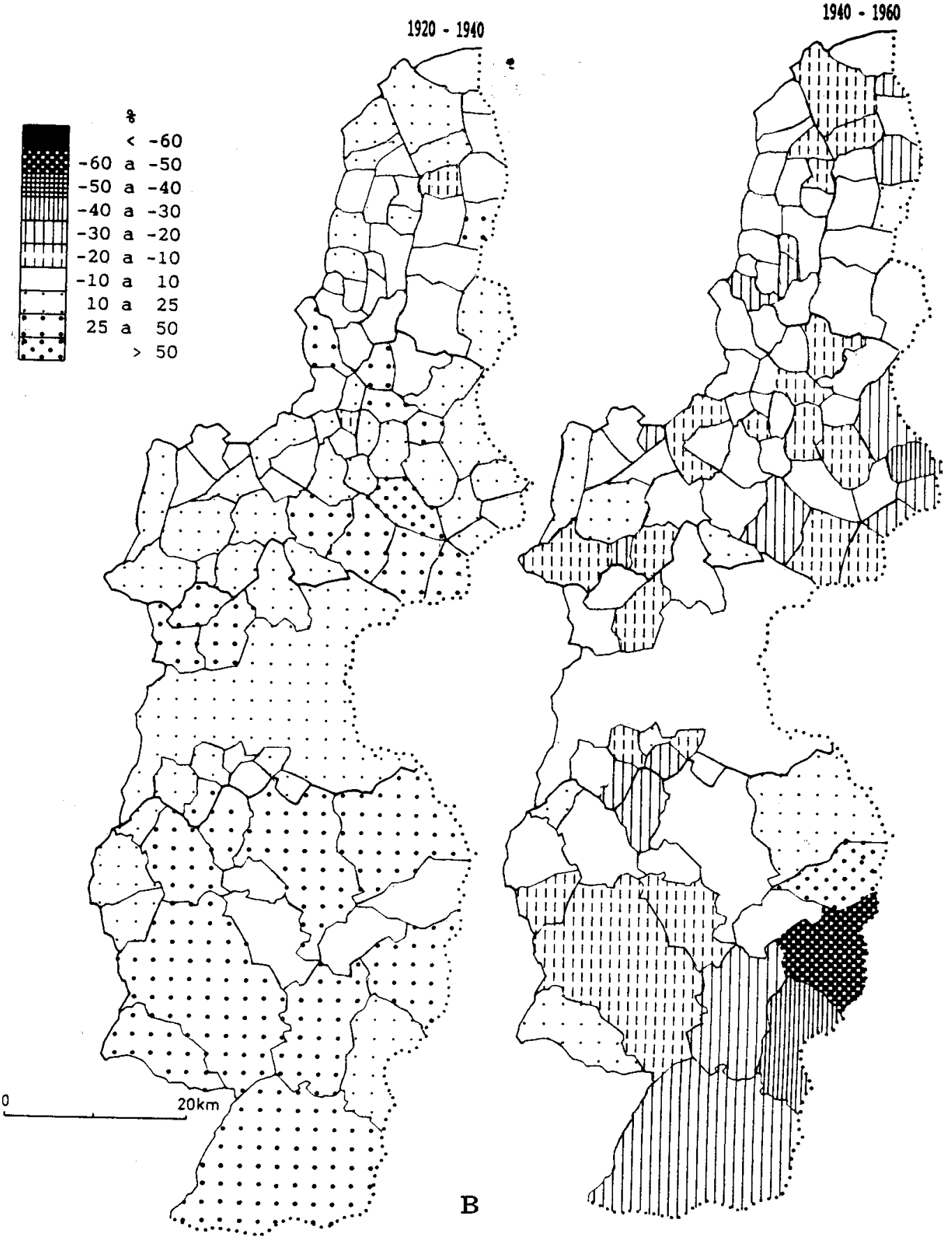

Fig. 10B - Variação da população residente, por freguesias, nos períodos 1920-1940 e 1940-1960. 


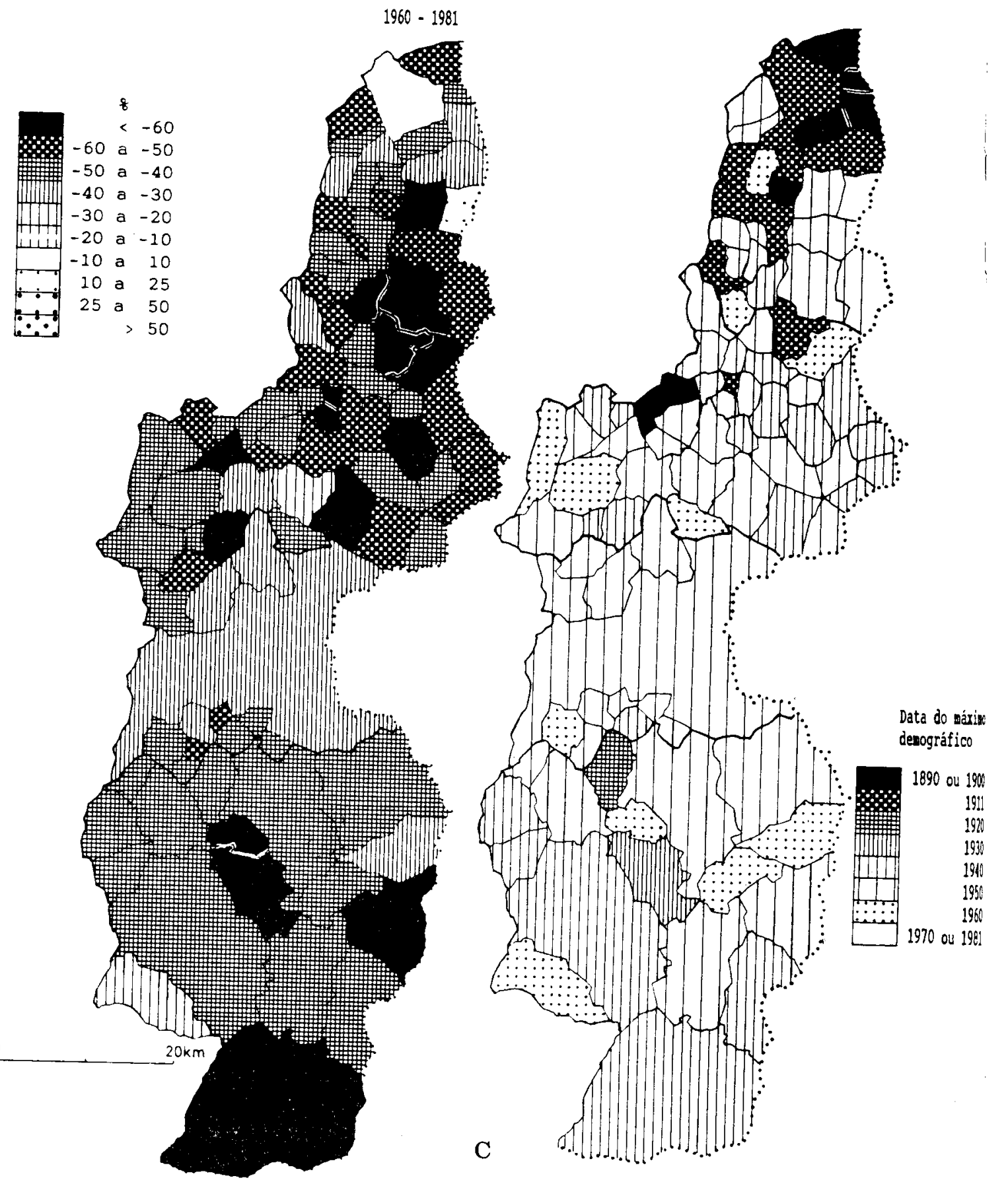

Fig. 10C - Variação da população residente, por freguesias, nos períodos 1960-1981, e anos dos máximos demográficos. 


\section{QUADRO XI}

Naturalidade da população residente (1960) (\%)

\begin{tabular}{|c|c|c|c|c|}
\hline Naturalidades & Almeida & Sabugal & Penamacor & Idanha \\
\hline Naturais do concelho de residência & 93,2 & 97,3 & 95,7 & 94,5 \\
\hline $\begin{array}{l}\text { Naturais de outros concelhos do } \\
\text { mesmo distrito } \ldots \ldots \ldots \ldots \ldots \ldots \ldots \ldots \ldots\end{array}$ & 4,1 & 1,1 & 2,3 & 3,7 \\
\hline $\begin{array}{c}\text { Naturais de outros distritos do } \\
\text { Continente } \ldots \ldots \ldots \ldots \ldots \ldots \ldots \ldots \ldots\end{array}$ & 2,4 & 1,4 & 1,8 & 1,5 \\
\hline 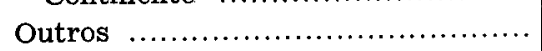 & 0,1 & 0,2 & 0,2 & 0,3 \\
\hline
\end{tabular}

mais de $90 \%$ da população residente era natural do concelho em que residia e mais de $\mathbf{9 7} \%$ deste ou de concelhos do mesmo distrito: a mais forte atracção sobre a população de outros distritos, no concelho de Almeida, prende-se, por certo, com as funções de Almeida e mais ainda de Vilar Formoso.

A situação de fronteira também não desencadeou fixações de estrangeiros: contavam-se então apenas 27 estrangeiros no concelho de Almeida (sendo 16 espanhóis e 5 brasileiros), 29 no de Sabugal (respectivamente 22 e 3), 10 no de Penamacor (dos quais 9 espanhóis) e 28 no de Idanha (sendo 27 espanhóis). Dado que os estrangeiros residentes eram em larga maioria do sexo feminino $(22,23,3$ e 17 , respectivamente) e oriundos de Espanha, a sua presença sugere relações de casamento, deslocando-se a esposa para o lugar/país de residência do marido, e sucedendo o inverso quando as raparigas portuguesas casam com rapazes espanhóis, como ainda hoje sucede, provavelmente não apenas pelas melhores perspectivas de vida no país vizinho.

Relativamente aos anos 70 , verifica-se que a mobilidade geográfica se complicou. Assim, a percentagem da população residente em 1981 que não mudou de concelho de residência relativamente a 1973 é mais baixa em Almeida e mais alta em Idanha, e é bastante mais alta entre a feminina do que entre a masculina; os imigrantes do país são muito menos significativos no concelho de Sabugal e, no geral, com mais elementos masculinos; por sua vez, os imigrantes do estrangeiro pesam bastante mais nos concelhos de Almeida e Sabugal do que nos de Penamacor e Idanha, onde por outro lado têm maior 
significado os emigrantes do concelho para outros concelhos, opondo-se os concelhos mais atingidos pela emigração (retorno de emigrantes do estrangeiro e das ex-colónias; retorno de filhos de emigrantes, para continuarem os estudos em Portugal, e das esposas, com deveres para com os familiares que permanecem no país) aos mais tocados pelo êxodo para as cidades dinâmicas da região e do país, com retornos por insucesso, desemprego continuado e velhice.

Deste modo, no período 1973-1981, os saldos migratórios foram positivos e importantes no concelho de Almeida, positivos mas moderados a fracos nos de Sabugal e Penamacor e negativos no de Idanha; relativamente a 1979, o saldo atenuou-se nos de Almeida e Sabugal, manteve-se negativo no de Idanha e reforçou-se no de Penamacor (Anexo I). Considerando separadamente as populações masculina e feminina, sobressai a maior mobilidade masculina (saldos sempre superiores, e fortes no concelho de Sabugal, mesmo relativamente a 1979, pela continuação dos retornos dos emigrantes) e a persistência de numerosas saídas para outros concelhos da população do de Idanha. Penamacor regista menores percentagens de população que não mudou de concelho de residência, tanto relativamente a 1979 como a 1973 e tanto na masculina como na feminina.

A crescente mobilidade da população e os muitos retornos apenas atenuaram a intensidade das perdas do decénio anterior, muito embora as conjunturas nacional e europeia não fossem favoráveis ao êxodo: de facto, o concelho de Sabugal perdeu $39,6 \%$ da sua população entre 1960 e 1970 e $17,6 \%$ de 1970 a 1981 ; a excepção do concelho de Almeida (-33,4 \% e - $2 \%$, respectivamente) deriva da dinâmica populacional de Vilar Formoso. Assim, em 1981, as populações concelhias naturais do próprio distrito iam de 86,5\% no de Almeida e 91,5\% nos de Sabugal e Penamacor a $94,4 \%$ no de Idanha. Por sua vez, as percentagens de população natural do Continente (quadro XII) mantinham o mesmo escalonamento norte-sul. O concelho de Almeida destacava-se então pelo maior peso da atracção dos retornos das ex-colónias e também pelos naturais de outros países, nomeadamente dos de destino da emigração, sendo secundado pelo de Sabugal e este pelo de Idanha (filhos de emigrantes nascidos no estrangeiro mas 


\section{QUADRO XII}

Naturalidades da população residente $(1981 ; \%)$

\begin{tabular}{|c|c|c|c|c|}
\hline Naturalidades & Almeida & Sabugal & Penamacor & Idanha \\
\hline Distritos & & & & \\
\hline Guarda .... & 86,5 & $9: 1,4$ & 2,0 & 0,3 \\
\hline Viseu & 1,3 & 0,5 & 0,4 & 0,2 \\
\hline Castelo Branco .... & 1,4 & 2,1 & 91,6 & 94,4 \\
\hline Lisboa $\ldots \ldots \ldots \ldots \ldots \ldots$ & 0,8 & 0,5 & 1,2 & 1,1 \\
\hline Outros $\ldots \ldots \ldots \ldots \ldots \ldots \ldots$ & 4,0 & 1,8 & 2,5 & $2, \mathbf{1}$ \\
\hline Continente ... & 94,0 & 96,3 & 97,7 & 98,1 \\
\hline 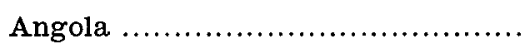 & 1,9 & 0,8 & 0,8 & 0,6 \\
\hline Moçambique & 0,9 & 0,2 & 0,2 & 0,5 \\
\hline 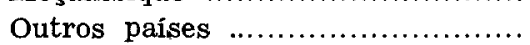 & 3,2 & 2,7 & 1,3 & 0,8 \\
\hline
\end{tabular}

Angola: 202 em Almeida; 152 no Sabugal; 76 em Penamacor; $89 \mathrm{em}$ Idanha.

Moçambique: 90 em Almeida; 42 no Sabugal; 22 em Penamacor; 74 em Idanha.

Outros países: predomínio das classes em idade escolar (6-20 anos).

residindo nas terras de naturalidade dos pais para a frequência da escola).

No seguimento do despovoamento rural muitas freguesias tornaram-se insignificantes em termos demográficos e as suas sedes reduziram-se a modestos lugarejos habitados por gente bastante idosa. São exemplos, a nível das freguesias e de norte para sul: Aldeia Nova (91 habitantes em 1981), Senouras (90), Vale da Coelha (68), Ruivos (89), Ruvina (118), Vale d'Ëguas (89), Idanha-a-Velha (121), etc.

A população residente sente a desertificação humana como eminente, a médio prazo: «a tendência desta freguesia é mesmo para acabar; a aldeia — Vale da Coelha — já só tem uma loja, que vende de tudo, e o seu proprietário aguarda a reforma para a fechar»; «os poucos novos que há - Nave do Haver - vão trabalhar clandestinamente para França»; «somos todos velhos; daqui a vinte anos não há cá ninguém (Aldeia da Ponte); vão saindo todos, uns para França outros para Lisboa; qualquer dia é uma aldeia despovoada, um deserto»; «ainda agora se vai para França e não vão mais porque não 
arranjam lá papéis; se abrisse a emigração não ficava çá Aldeia Velha - nem um dos que ainda são capazes de pegar nas botas»; "tirando eu e mais dois ou três, são só velhos; agora ainda se vê cá gente (Quadrazais), mas chegando o Inverno não se vê ninguém»; «foi tudo embora, metade para Lisboa e os outros para França e Alemanha; isto é uma terra de velhos, que vão vivendo das pensões» (Aranhas); «a tendência desta terra é para desaparecer; os novos, chegando à idade da tropa, vão-se embora; seguramente $70 \%$ dos habitantes tem mais de 55 ou 60 anos» (Aldeia de João Pires); «não há homens para trabalhar, nem a mais nem a menos: quase não há homens válidos mas quase não há trabalho para fazer; qualquer dia põe-se uma placa à entrada da terra a dizer FECHADA» (Monforte da Beira) ; «não há desemprego porque também não há praticamente activos. Chegando à idade de fazer vida os moços que por aqui ainda há vão trabalhar para fora, ao mesmo tempo que os reformados vão voltando» (Salvaterra do Extremo), etc.

\section{Campos de PopUlaçóes ENVELHECIDAS}

As migrações internas, a emigração e os retornos conduziram a fortes desequilíbrios na composição etária da população residente, ao mesmo tempo que reforçaram a tendência geral de diminuição da dimensão das famílias, menor na Beira Baixa (fig. 11A), e diminuiram as taxas de masculinidade, sempre relativamente baixas, embora menos no concelho de Almeida (fig. 11B), que também regista menor número de famílias sem activos, maior taxa de actividade, designadamente da população masculina, ao inverso de Idanha, muito embora a ponderação da população activa pela potencialmente activa (15-60 anos) apague essa imagem favorável, que então pouco difere da de Idanha pela taxa de actividade bastante baixa da sua população feminina (Anexo I).

O concelho de Almeida registou, em 1981, maiores percentagens de população de menos de 15 anos e menores da de 60 anos e mais, enquanto no de Idanha a situação era inversa, independentemente dos sexos. Os perfis das respectivas pirâmides etárias evidenciam claramente os efeitos directos e indirectos do êxodo nas classes etárias potencial- 
mente activas e nas infantis, menos cavadas no concelhơ de Almeida e mais no de Idanha (fig. 12). Tendo em conta a estrutura do povoamento, verificamos que as percentagens de população de 60 anos e mais são maiores nos aglomerados muito pequenos, nomeadamente em Almeida, e nos pequenos, e diminuem acentuadamente com o aumento da dimensão dos núcleos (fig. 13). Ou seja, os maiores aglomerados têm populações menos envelhecidas e mais equilibradas quanto à composição por sexos, embora não necessariamente mais activas.

A ruralidade dos valores etários concelhios pode ser avaliada considerando como amostra significativa da população dos campos a população agrícola familiar computada em 1979 pelo RAC. Os seus níveis de envelhecimento (popu-
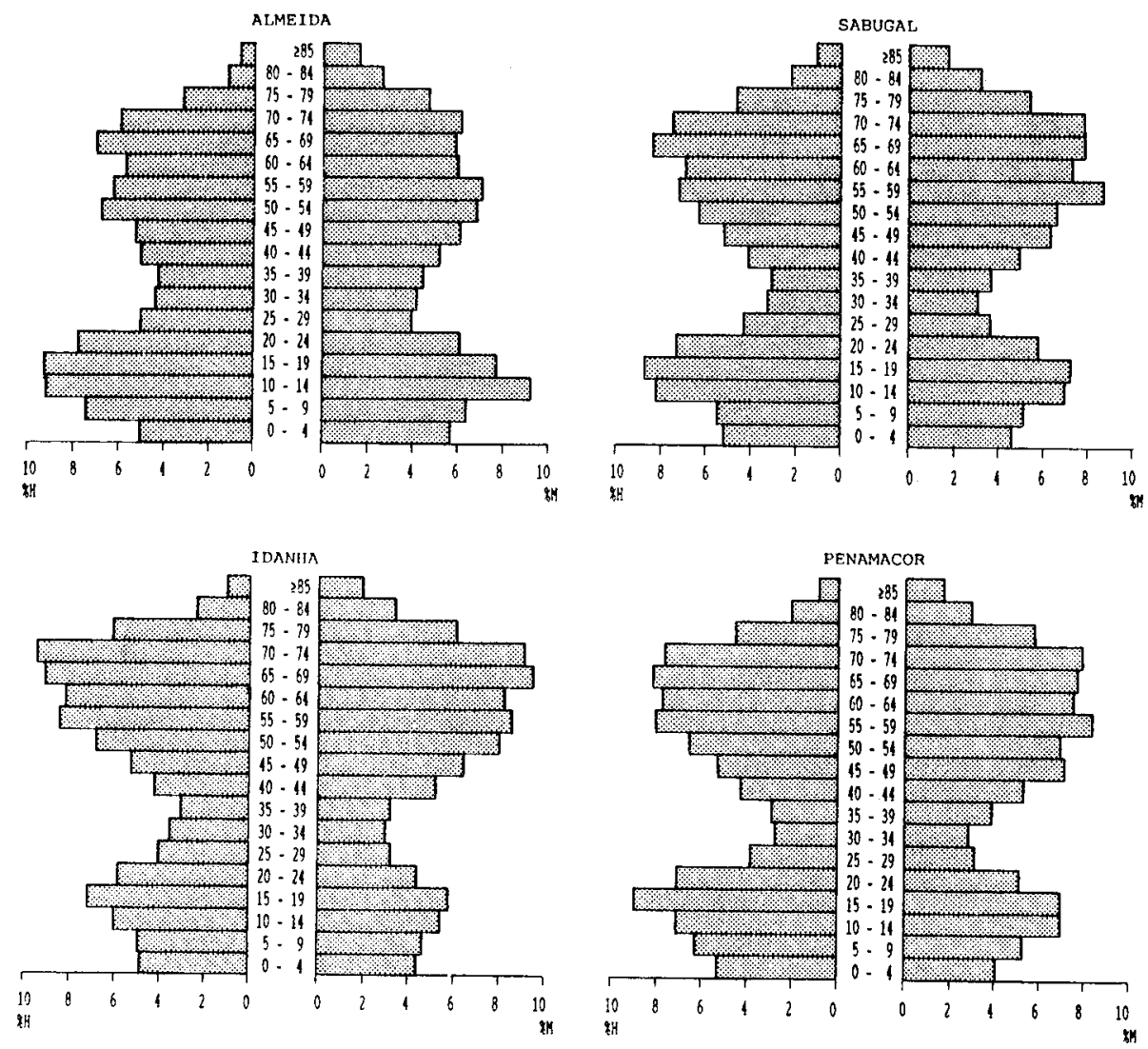

Fig. 12-Pirâmides etárias concelhias, em 1981. 
\& população

residente
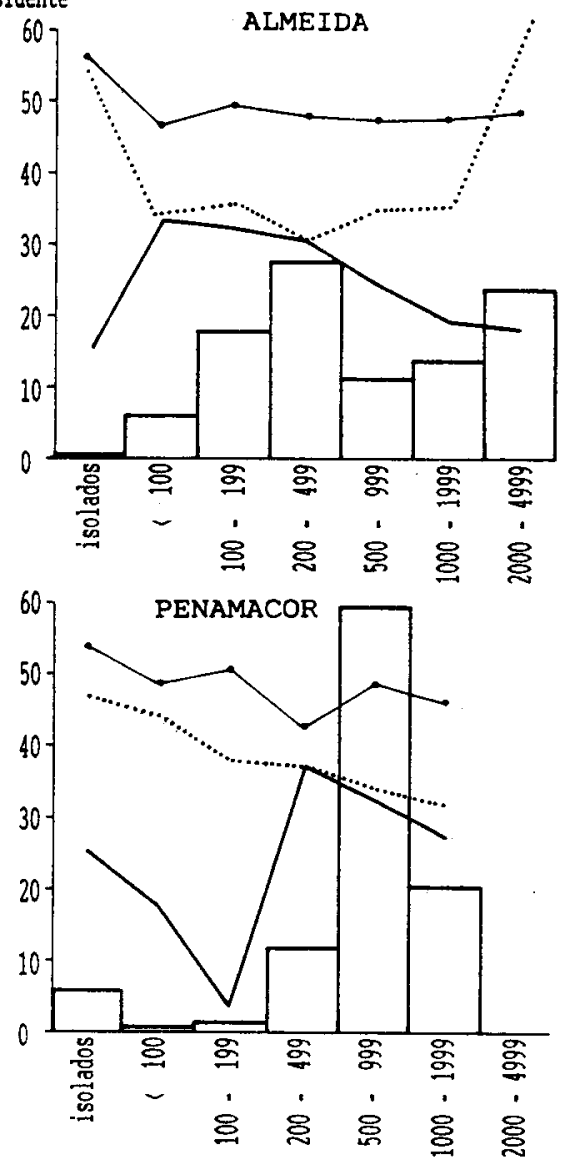

q populaçào

residente

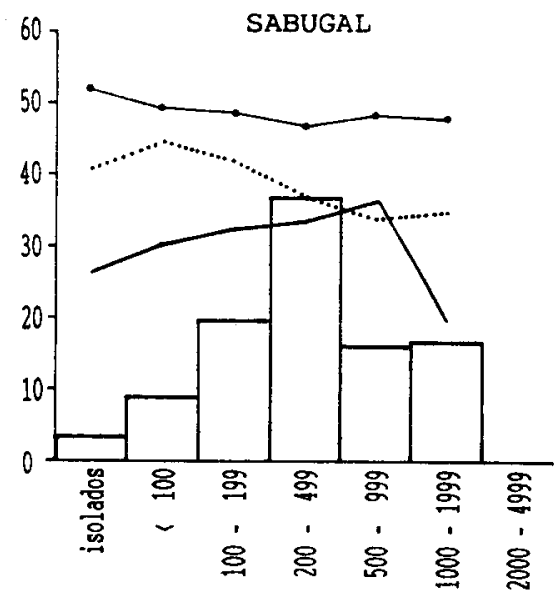

IDANHA

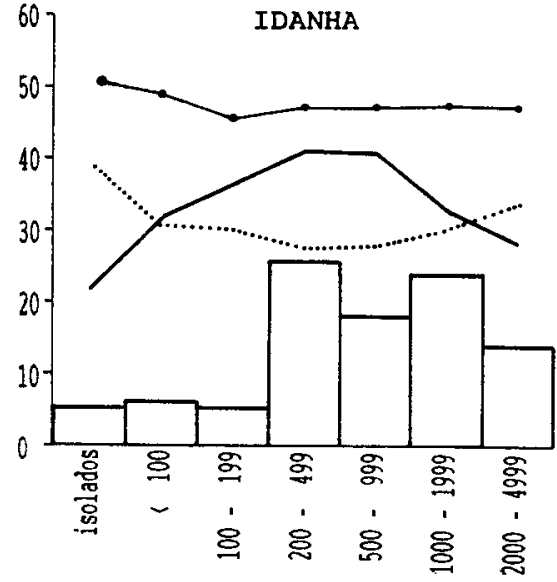

\%opulação $\geq 60$ anos

Taxa de actividade da população residente Taxa de masculinidade

Fig. 13 - Estruturas do povoamento em 1981 (percentagem de população residente em lugares de várias classes dimensionais), por concelhos, e diferenciação paralela das taxas de envelhecimento, de actividade e de masculinidade da população residente.

lação de 65 anos e mais) eram então bastante acentuados: $20,9 \%$ no concelho de Almeida, 25,1\% no de Sabugal, 22,3 $\%$ no de Penamacor e $27,8 \%$ no de Idanha. A população de menos de 20 anos representava, por sua vez, 35,3\% no de 
Almeida mas somente $30,3 \%$ no de Sabugal, $29,7 \%$ no de Penamacor e 20,7\% no de Idanha. Correspondiam-lhes, aliás, perfis etários muito desequilibrados (tal como taxas de masculinidade fortemente perturbadas entre os adultos mais ou menos jovens) e populações activas nas explorações muito envelhecidas, com grande peso da de 55 a 65 anos e forte representação da de 65 anos e mais. De facto, a actividade na exploração familiar aumenta com a idade, não regularmente pela perturbação introduzida pelo serviço militar, alcança valores superiores a $90 \%$ aos 45 anos, mantém-nos até aos 65 anos e diminui um pouco a partir de então, se bem que entre os muito idosos, de $\mathbf{7 5}$ anos e mais, ainda seja superior a 70\%: os velhos camponeses procuram trabalhar até à morte, embora não necessariamente de forma intensiva, cultivando a terra que é sua e até vendendo sazonalmente jornas quando as oportunidades são muitas e os salários atraentes, como na apanha da azeitona; assim conseguem economizar na alimentação, pelo autoconsumo, e obter complementos monetários das reformas, que lhes permitem amealhar algum dinheiro para fases da vida ainda mais difíceis, de doença e invalidez; assim se perpetuam alguns ramos agrícolas tradicionais exigentes em mão-de-obra e dificilmente rendíveis e se mantém ainda humanizado quase todo um campo que tende de há muito para o abandono.

Mas os concelhos são espaços muito heterogéneos quanto às estruturas etárias da população residente. A análise destas por freguesias e por grandes grupos de idades (fig. 14) permite-nos evidenciar o forte envelhecimento da população da maior parte das freguesias do concelho de Idanha (mais de $30 \%$ de população com 60 anos e mais), máximo nas de Proença-a-Velha (54\%), Rosmaninhal (52\%), Salvaterra do Extremo (52\%) e Alcafozes $(48 \%)$, bem como nas mais fronteiriças do concelho de Sabugal, designadamente Forcalhos (49\%), Quadrazais (46\%) e Lageosa (45\%), e também Aldeia do Bispo (41\%), Aldeia da Ponte $(43 \%)$ e Alfaiates, vizinhas das anteriores.

A norte, no concelho de Almeida, alarga-se a mancha dos valores percentuais situados entre $35 \%$ e $45 \%$. Inversamente, as mais baixas percentagens de população residente com 60 anos e mais ocorrem em Vilar Formoso $(11,3 \%)$ e Almeida $(19,8 \%)$ 


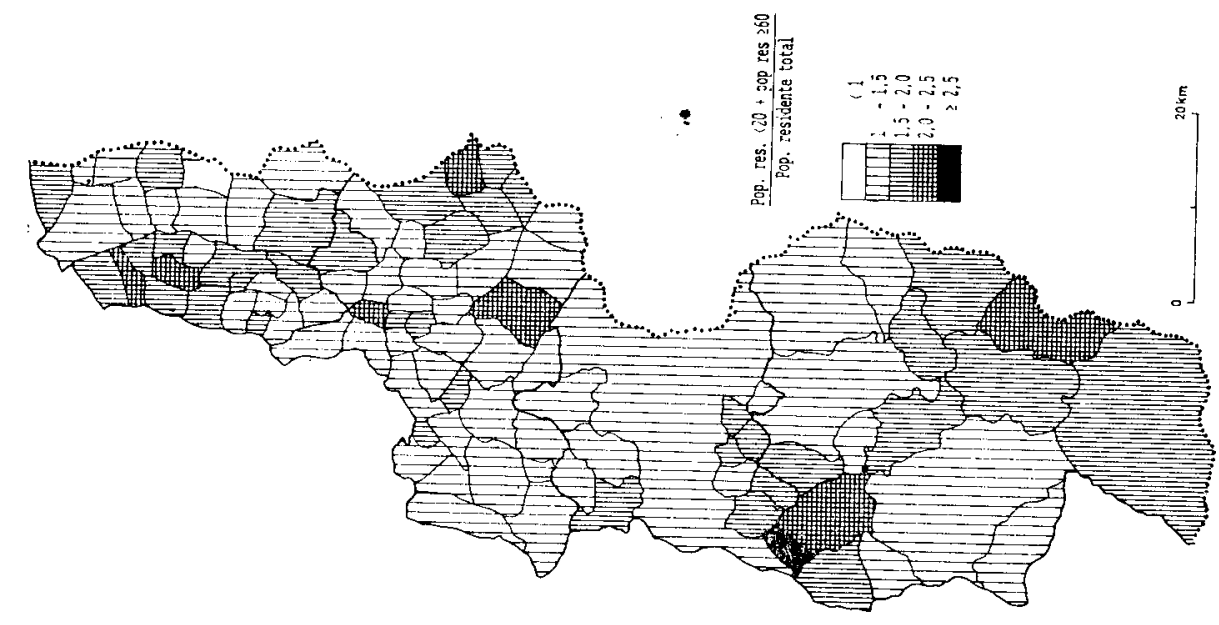

唯
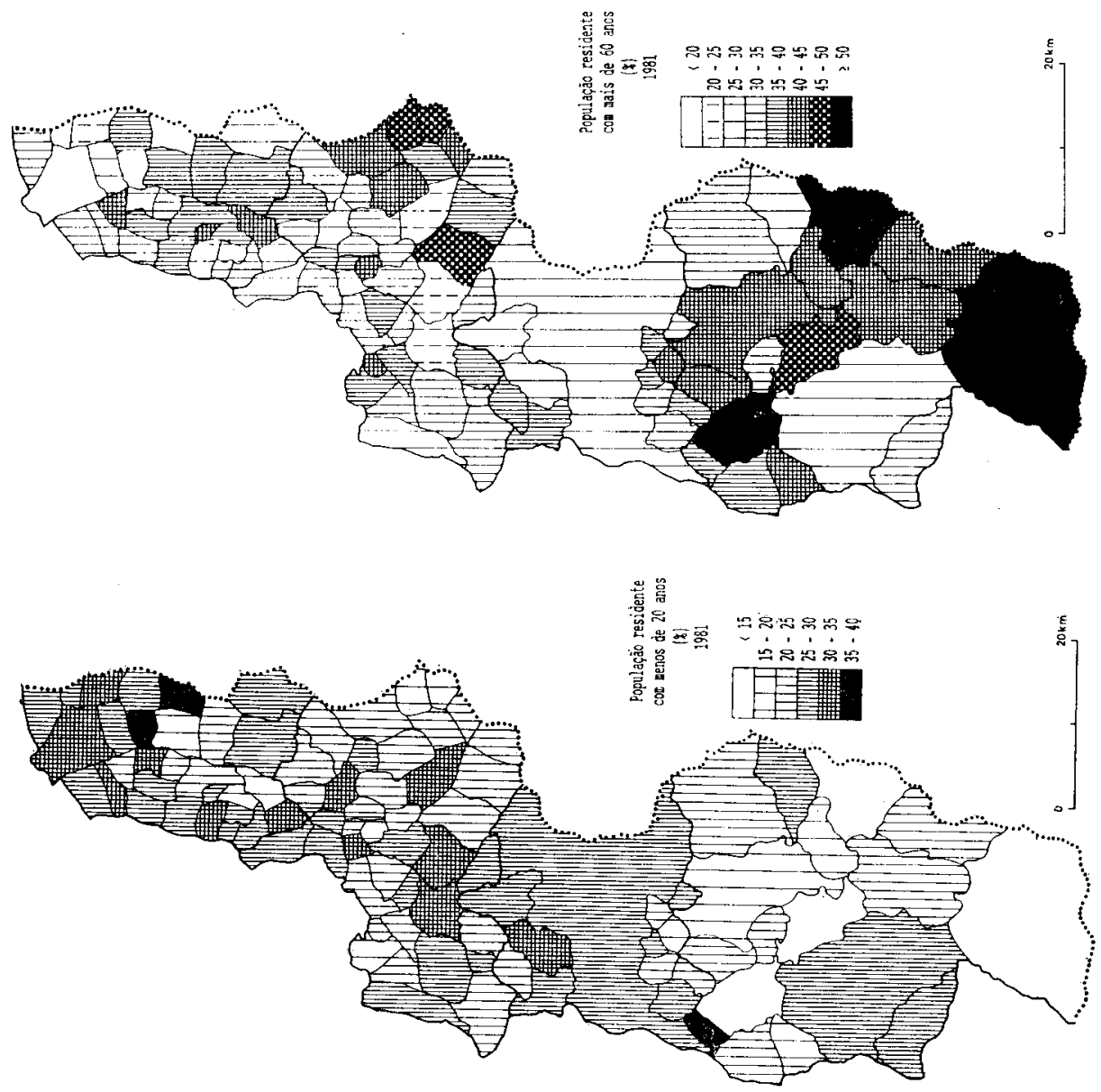
e ainda na freguesia das Naves, mas nas demograficamente muito pequenas como esta os valores percentuais perdem algum significado. De notar que mesmo as freguesias de Idanha-a-Velha (27\%), Penamacor (28\%) e Sabugal (21\%), que compreendem as sedes concelhias, e as de Monfortinho (27\%) e Souto $(24 \%)$, respectivamente de forte actividade turístico-termal e secundária e comercial, registam valores superiores a $20 \%$.

Considerando, por outro lado, a população residente jovem, de menos de 20 anos (fig. 14), ressaltam estas últimas freguesias, bem como Naves (39\%), Aldeia de Santa Margarida (39\%) e Vilar Formoso (36\%), com os valores percentuais mais altos; os mais baixos ocorrem em freguesias do concelho de Idanha, nomeadamente em Alcafozes (13\%), Salvaterra do Extremo e Rosmaninhal (14\%), Proença-a-Velha (15\%), Oledo (16\%), Monsanto (17\%), Toulões (19\%) e Medelim $(20 \%)$; nos concelhos de Sabugal e Almeida encontram-se algumas freguesias com valores percentuais de população jovem um pouco inferiores a $20 \%$, como Forcalhos, Lageosa, Pousafoles e Ruvina (19\%) no primeiro e Castelo Bom, Porto da Ovelha e Monte Perobolso no de Almeida.

Um indicador bem sugestivo do envelhecimento demográfico da zona raiana é o pequeno número de alunos a frequentar as escolas primárias, o que conduzirá inevitavelmente ao fechar de muitas delas a curto prazo. De facto, em 1989, no concelho de Almeida, a de Vale da Coelha contava 1, as de Azinhal e Castelo Bom 3, a da Amoreira 4, as de Castelo Mendo e Monte Perobolso 5, as de Ade, Aldeia Nova, Leomil, Mesquitela e Senouras 6, as de Cabreira, Naves e Pera 7, as de Junça e Malpartida 8, as de Freineda e S. Pedro do Rio Seco 9, a de Malhada Gorda 12, etc. A quase ausência de crianças em idade escolar ameaçava também algumas freguesias do concelho de Sabugal, no mesmo ano, mas sem a generalidade e a gravidade do de Almeida. Assim, a frequência das escolas de Baraçal e Lomba reduzira-se a 4, em Pousafoles a 5, Moita, Nave e Pena Lobo a 6, Badamalos a 7, Lageosa a 8 , Bismuda a 10, Aldeia Velha a 11, Quadrazais a 12, Forcalhos a 13, Aldeia da Ponte e Vale de Espinho a 14, etc. Mais a sul, pela maior concentração do povoamento, os números absolutos da frequência escolar eram menos dramáticos: Bem- 
posta 11, Vale da Senhora da Póvoa 14, Aldeia de João Pires 15 ... mas apenas 4 na escolia primária de Idanha-a-Velha.

A síntese dos desequilíbrios etários da população residente pode ser obtida pelo coeficiente de dependência $(<20$ anos +60 anos e mais/20-60 anos ) (fig. 14): em posição privilegiada sobressai então, de novo, a freguesia de Vilar Formoso $(0,9)$, a que se seguem Almeida $(1,01)$, Sabugal $(1,06)$, Monfortinho $(1,09)$, Idanha-a-Nova $(1,15)$ e Idanha-a-Velha $(1,16)$; no outro extremo, destacam-se as freguesias de A. Santa Margarida $(3,08)$, Segura $(2,15)$ e Proença-a-Velha $(2,16)$ no concelho de Idanha, Forcalhos $(2,18)$ e Vale Longo $(2,02)$ no de Sabugal e Leomil $(2,04)$ e Azinhal $(2,15)$ no de Almeida; as manchas desfavorecidas com maior continuidade encontram-se no interior do concelho de Almeida, no extremo oriental do de Sabugal e cobrem vasta área do de Idanha.

\section{CoMPLEXIDADE DAS ESTRATÉGIAS dE SOBREVIVENCIA DAS FAMILIAS}

A agricultura constitui a actividade dominante das populações rurais da Raia Central. Trata-se, todavia, duma agricultura insuficiente em termos de emprego e de rendimentos, pelas estruturas agrárias e pelos sistemas agrícolas dominantes.

A diversidade das estruturas empresariais e a forte oposição entre os concelhos de norte e os de sul, de maior concentração fundiária (as explorações de $\mathbf{1 0 0}$ ha e mais ocupavam, em 1979, $67 \%$ da superfície total no concelho de Penamacor e $79 \%$ no de Idanha, mas apenas $31,4 \%$ no de Almeida e 6,2 \% no de Sabugal), não escondem o peso social das pequenas explorações: em 1979, as de menos de 5 ha representavam cerca de metade do universo no concelho de Idanha, mas $3 / 4$ ou mais nos restantes; às de menos de 3 ha cabiam 54 a $62 \%$ em todos os concelhos, e às de menos de 1 ha, $11 \%$ no de Almeida e $1 / 4$ ou mais nos outros, com relevo para Idanha (mais de 1/3), sem inclusão das minúsculas, inquiridas pelos questionários simplificados.

A área média das explorações à escala das freguesias, embora de significado modesto, evidencia os principais contrastes espaciais do controlo da terra; destacam-se então os valores particularmente altos de Rosmaninhal, Idanha, Alcafozes, Salvaterra do Extremo e Segura, todas do concelho de 
Idanha, o valor ainda alto da vasta freguesia de Penamącor e os particularmente baixos de muitas outras. Nestas a pequena dimensão das explorações é agravada pelo seu parcelamento num elevado número de blocos minúsculos, fechados por muros de pedra e dispersos, obrigando a percursos longos e inúteis, condicionando a pecuária, particularmente o pastoreio de pequenos ruminantes, e impossibilitando a mecanização.

No que respeita aos sistemas agrícolas, sublinhem-se os baixos rendimentos e produtividades, no prolongamento dos ramos e das técnicas do passado. Naqueles destacam-se: os cereais praganosos em todos os concelhos; a batata e a vinha nos concelhos de norte; o olival e a floresta nos de sul; pousios, prados e pastagens permanentes, de norte a sul; grandes e pequenos ruminantes, também de norte a sul mas os primeiros predominando a norte; e os incultos com matos e estevas, sobretudo nos concelhos de Sabugal e Almeida. Trata-se de sistemas no geral pouco intensivos e só localmente beneficiados pela rega, no âmbito de pequenos regadios individuais (Sabugal) ou de aproveitamentos hidroagrícolas estatais (Idanha). A rega permitiu o desenvolvimento de pomares (maçãs, peras, pêssegos) e, na campina de Idanha, de culturas horto-industriais (tomate; tabaco).

Estes cultivos figuram entre as principais inovações dos últimos decénios, a par do milho, do girassol, do melão, do pepino, de plantações localizadas de olivais para azeitona de conserva, de castanheiros, aveleiras, diospiros, framboesas e silvas, bem como dos eucaliptos. No campo da pecuária ressaltam o melhoramento dos pastos, a racionalização do pastoreio, o cultivo de forragens, a expansão dos bovinos de carne e leite, a dos pequenos ruminantes, a de suínos em malhadas, a par da apicultura e da truticultura.

Quanto às técnicas persistem ainda as tradicionais, com alfaias manuais e de tracção animal, mas registou-se a difusão de pesticidas, além da generalização dos adubos, da mecanização dos transportes, dos trabalhos culturais (tractores, motocultivadores, ceifeiras, debulhadoras, descaroladores), da rega e da ordenha (dos bovinos e até mesmo de ovinos), a construção de estufas para secagem do tabaco, etc.

Certas produções são laboradas nas explorações (presuntos, queijos, azeite), apesar do desenvolvimento de algumas uni- 
dades industriais agroalimentares, privadas ou cooperativas: traduzem a preocupação de aumento do seu valor comercial, com acréscimo das receitas dos produtores.

A insuficiência dos rendimentos agrícolas levou as famílias à busca de receitas complementares, através do fabrico de carvão de lenha, da caça, da apanha de cogumelos e amoras silvestres, da busca de ouro nos ribeiros (nas épocas de maior desemprego: Rosmaninhal, Monforte, Penha Garcia), de produções artesanais diversas (tecelagem de lã e de trapos, rendas e bordados, objectos de barro e madeira, etc.), do aluguer de máquinas agrícolas, bem como de quartos com serviço de pequeno almoço a turistas (termas, caça), da venda da força de trabalho para minas e termas, construção civil e indústrias induzidas (mobiliário, carpintaria), indústrias novas (confecções), actividades terciárias (pensões, restaurantes, cafés, serviços oficiais), e obviamente do contrabando e da emigração.

São assim múltiplas as situações familiares de pluriactividade: em 1979, os produtores pluriactivos representavam $57 \%$ no concelho de Penamacor, $46 \%$ no de Idanha, $33 \%$ no de Almeida e $25 \%$ no de Sabugal; a pluriactividade interessava fundamentalmente os elementos masculinos dos agregados familiares $(42 \%$ no concelho de Penamacor, $41 \%$ no de Idanha, $25 \%$ no de Almeida e 22,5 $\%$ no de Sabugal), que laboravam fora da exploração na agricultura (sobretudo nos de Idanha e Penamacor), na construção civil (mais no de Sabugal) e em actividades terciárias $(58,8 \%$ no de Almeida, $39,8 \%$ no de Idanha, $35,7 \%$ no de Penamacor e $33,5 \%$ no de Sabugal).

Outros membros das famílias agrícolas trabalhavam fora mas comportavam-se como hóspedes relativamente à exploração. Em conjunto com os pluriactivos representavam percentagens elevadas da população activa, em 1981, noutras actividades.

A manutenção de uma economia minimamente diversificada e de actividades terciárias de apoio à produção, e sobretudo ao consumo, que assegurem alguma qualidade de vida, parece depender destas estratégias familiares de pluriactividade arrastando plurirrendimento. Mas nem todas as situações de plurirrendimento se identificam com pluriactividade: são bastante comuns as pensões de velhice e invalidez e os juros 
dos depósitos a prazo, em relação com o acentuado envelhecimento e a generalização da emigração (possibilidades de aforro). Com efeito, em 1979, os agregados familiares agrícolas com receitas provindo exclusivamente das suas explorações representavam apenas $6 \%$ do universo do concelho de Penamacor, $11 \%$ de Idanha, $22 \%$ de Sabugal e $26 \%$ de Almeida. Ao nível das freguesias, as percentagens são particularmente baixas por quase toda a Beira Baixa; valores ainda baixos ocorrem ao longo da fronteira, de Almeida à Lageosa; relacionam-se com o acesso a outras oportunidades locais de ganhos, mesmo se apenas na agricultura patronal, mas também com o êxodo rural, através da emigração e do envelhecimento das famílias agrícolas (fig. 15 e 16).

\section{Que Desenvolvimento Agricola e RuRal?}

Os problemas do desenvolvimento das regiões fronteiriças portuguesas são em grande medida os das regiões interiores, subdesenvolvidas no quadro nacional e comunitário, agravados pela sua mais forte marginalização e isolamento, de que a Raia Central constitui um bom exemplo.

A plena integração de Portugal e Espanha na Comunidade e a criação do Mercado Interno Europeu (1993), com a supressão de todas as barreiras à livre circulação de pessoas, mercadorias, serviços e capitais, modificarão o relacionamento dos dois estados peninsulares, em especial no que respeita às trocas comerciais (fluxos mais densos e mais volumosos) e às regiões de fronteira. Para estas sobressaem perspectivas de abertura de novas passagens, de desenvolvimento da cooperação, nomeadamente quanto a infra-estruturas, equipamentos e serviços comuns ou complementares (estradas e pontes; sistemas de utilização de recursos, como os de abastecimento de água; tratamento de lixos; serviços de apoio às empresas; ensino e formação profissional; actividades recreativas e culturais, etc.), bem como ao ordenamento do território e à protecção do ambiente, sem esquecer o possível alargamento espacial das oportunidades de emprego, com intensificação das migrações regulares de trabalho. $O$ equilíbrio e a harmonia devem caracterizar as mudanças regionais esperadas, sem o 


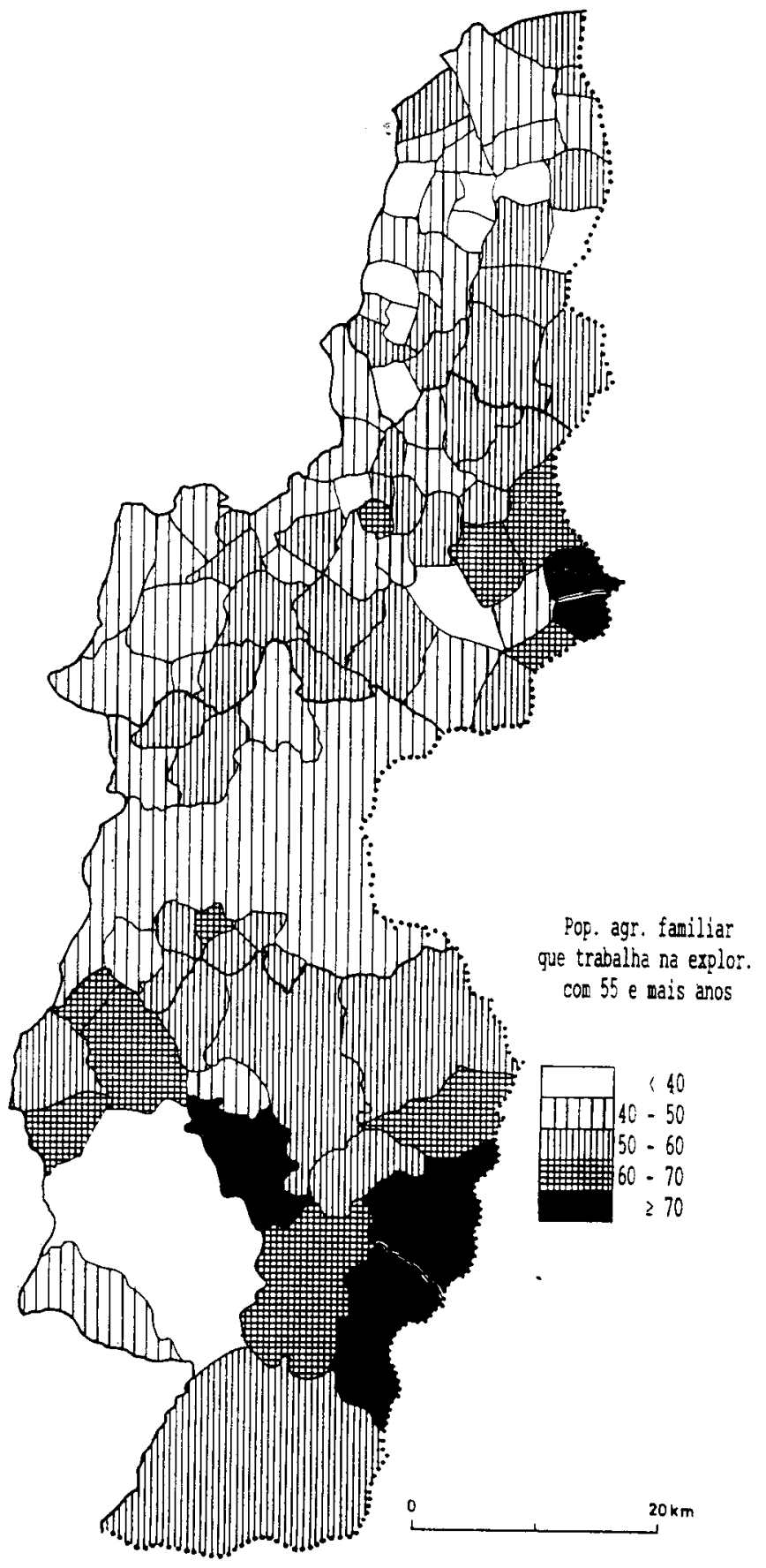

Fig. 15-Percentagem da população agrícola familiar que em 1979 trabalhava nas suas explorações, de 55 anos e mais. 
que persistirá a «Raia do Subdesenvolvimento», pelo menos dum dos lados da velha fronteira.

A Raia Central constituía um dos seus segmentos mais desfavoráveis: a passagem faz-se regularmente por Vilar Formoso e Segura e apenas periodicamentne por outros lugares; as estradas que ligam as aldeias entre si e com as sedes de concelho e as capitais dos distritos não permitem tráfegos intensos e rápidos. Nos anos 80 registaram-se, todavia, sensíveis melhorias das ligações ao exterior, através de obras importantes nos eixos Aveiro-Guarda-Vilar Formoso, Lisboa-Castelo Branco e Guarda-Covilhã-Fundão. As maiores acessibilidades potencializam forças de atracção sobre investimentos, designadamente industriais e terciários, que poderão garantir-lhe vida própria mais dinâmica, para além do reforço da sua função como espaços de passagem de bens e pessoas, sobretudo se seguidas de melhoramento das comunicações em geral, das intra-regionais, das condições de vida e de trabalho e das perspectivas profissionais e sociais, cuja mediocridade a tornaram repulsiva.

Em que medida os campos da Raia Central participarão desta nova dinâmica? Por certo,

- pelo apagar de sentimentos de isolamento e abandono político, com as novas condições de acessibilidade, a diferentes escalas espaciais, através das facilidades de transporte rodoviário e também ferroviário (melhoramento das vias);

— pela expansão das actividades não agrícolas de localização urbana ou mesmo rural, transformando ou não matérias-primas regionais, designadamente do sector primário, proporcionando empregos à população das zonas envolventes e dinamizando indirectamente os mercados (procuras alimentares elásticas relativamente aos níveis dos salários);

- pela densificação da rede dos equipamentos terciários dos centros urbanos e das principais aldeias (ensino, saúde, assistência, prestação de serviços diversos, venda de bens de consumo e de produção, etc.), capazes de responder qualitativamente à evolução da procura local, sub-regional e regional; 
- e, sobretudo, pelo desenvolvimento e modernização "das actividades e funções clássicas destes espaços rurais, uma vez limitadas as oportunidades de emigração para outras áreas do país e da Comunidade (redução do emprego; crescente selectividade) e intensificados os retornos.

Neste campo sobressaem, por um lado, a agricultura, pecuária, silvicultura e apicultura; e por outro, a caça, pesca, diversos tipos de turismo (motivações e clientelas; termalismo, turismo cultural e ecológico, agroturismo), mesmo o turismo de habitação em meio rural (utilização do parque habitacional de qualidade construído pelos emigrantes), o artesanato, etc.

As soluções não são, porém, simples. Como região desfavorecida, de montanha ou em vias de despovoamento, a Raia Central vem beneficiando de majorações nos subsídios aos investimentos do FEOGA-Orientação e de prémios e ajudas directas aos agricultores (segundo as áreas cultivadas e os efectivos animais, dentro de certos limites). Sabemos que a Beira Interior, de que faz parte, recebeu, em 1987 e 1988, 11,6\% dos pagamentos efectuados como indemnizações compensatórias, percentagem semelhante dos apoios à criação de infra-estruturas e financiamento de acções complementares inseridas no PEDAP, mas apenas $8,2 \%$ do investimento no quadro do Regulamento $355 / 77$, além de $15,4 \%$ dos montantes do PLIAA (programa de lançamento de infra-estruturas da agricultura associada, do Orçamento do Estado) e 10,5\% dos correspondentes ao PNADAA (programa nacional de apoio ao desenvolvimento das associações agrícolas) em 1987 e 1988, etc. Não nos é porém possível identificar as parcelas que couberam à faixa raiana, verificar a possível mudança das condições de produção e o alcance das novas perspectivas para os jovens agricultores. De qualquer forma, se algumas empresas agrícolas poderão pelo seu desenvolvimento, intensificação e modernização manter-se ou tornar-se viáveis, muitas outras continuarão como «insuficientes» quanto a emprego dos membros dos agregados familiares respectivos e quanto a rendimentos, valorizando-se mais ainda as estratégias tradicionais de pluriactividade e de plurirrendimento: autoconsumo; pequena produção comercial, tanto quanto possível de qualidade; outras 
actividades, da recolecção ao terciário (que vai ao encontro da economia dos tempos livres), capazes de proporcionarem receitas; ajudas directas, em recompensa da conservação das paisagens humanizadas, e outras fontes de rendimento não ligadas ao trabalho.

\section{RASUME}

Les campagnes de la Beira frontalière du point de vue du développement rural. - L'article analise la campagne proche de la partie centrale de la frontière luso-espagnole dans une perspective de développement rural. En introduction est mis en évidence le sous-développement et le caractère socio-économique déprimé de toute ou de presque toute la région frontalière, ce qui est, dans une certaine mesure, original dans le cadre de la CEE: c'est une vaste zone peu accessible, sous-développée, fortement touchée par l'exode vers la façade atlantique et par l'émigration, ce qui explique l'effondrement des densités humaines et la désertification des campagnes, bref, une vaste périphérie intérieure à l'échelle du Portugal, voisine de la périphérie intérieure de l'Espagne, elle aussi peu accessible, marginalisée, sous-développée et également très touchée par l'exode et par l'émigration. Donc, un vrai couloir de sous-đéveloppement.

Parmi les causes principales, il faut tenir compte tout d'abord des stratégies militaires et politiques des deux pays, des politiques nationales de développement, essentiellement maritimes et périphériques, la crainte mutuelle de concurrence puisque les potentialités des deux pays ne sont pas nécessairement complémentaires et sans doute aussi les conditions naturelles difficiles qui ont d'ailleurs permis d'intégrer tous ces espaces dans les régions défavorisées, selon les directives communautaires, en raison de l'altitude et des pentes ou du poids de l'agriculture dans l'emploi, ou encore de l'intensité des pertes récentes de population, au point de devenir bientôt le Portugal du vide.

Les passages frontaliers se font seulement en quelques points, surtout pour les hommes et les marchandises de destination ou de provenance lointaine, généralement au-delà des Pyrénées. Mais les populations des deux côtés de la frontière ont su vaincre l'imperméabilité et ont osé intégrer dans leurs stratégies de survie toutes les potentialités de l'illégal et du clandestin: échange de travailleurs selon les opportunités de travail (agriculture, bâtiment, «restauration»...), selon aussi le niveau des salaires et la valeur relative des monnaies: petit commerce de détail; commerce de gros de produits nationaux et d'importation (guides locaux connaissant les sentiers et les autorités des deux côtés de la frontière, de façon à rentabiliser les longues nuits de «travail»). Tout cela a réussi dans la partie frontalière de la Beira Intérieure, espace essentiellement rural et agricole, touché par l'excde et rempli de jachères et de maquis, sans diversification de l'économie et de l'emploi, sauf dans 
le bâtiment et les industries induites (maisons neuves pour les émigrếs) et dans le tertiaire improductif.

Les familles agricoles sont pluriactives et ce sont leurs membres qui occupent la plupart des postes de travail non agricole. Ce sont aussi des familles âgées, ce qui crée de multiples situations de pluri-revenu sans pluriactivité (pensions de retraite). Dans les années 70 et 80 quelques innovations (activités productives, infrastructures, équipements) ont amélioré le niveau et les cadres de la vie locale et régionale. La. pleine intégration à la CEE doit permettre de poursuivre dans cette voie, en intensifiant les rapports avec la population de l'autre côté de la frontière et en dépassant par une conjugation d'efforts les principaux handicaps, notamment l'isolement. L'élaboration conjointe d'un plan de développement et d'aménagement (OID) de cette partie du territoire frontalier peut constituer un tournant dans les rapports entre les deux pays et dans les tendances de l'évolution économique et social régionales. Celles-ci seront renforcées, au niveau rural, par l'élaboration des PDAR's (plans de développement agricole regionaux), permettant un meilleur encadrement des initiatives au niveau du PEDAP (Programme Spécifique de Développement de l'Agriculture Portugaise) ou du Reg. 797 de la CEE (modernisation et développement des exploitations agricoles).

\section{ABSTRACT}

The countryside near the central part of the Portuguese boundary, in view of rurcl development. - The article analizes the countryside near the central part of the Portuguese boundary, in view of rural development. This paper begins by highlighting the underdevelopment and the depressed economic and social character of nearly all the boundary region, that is in a certain way an original trait within the EEC. It is a vast underdeveloped region with poor accessibility, highly affected by the exodus to the coast and emigration, which explains the decreasing human density and desertion of the country, so a large portuguese internal periphery, neighbour to the Spanish internal periphery, which is also nearly inacessibly, discriminated, underdeveloped and afected by the exodus and emigration. We can therefore speak of an underdeveloped strip.

Among the principal causes to be considered are military and political strategies of both countries, the national policies of development, mainly coastal and peripheral, the fear of mutual competition once the potentials of the two countries are not necessarily complementary, and undoutbly the natural difficult conditions, which have to be considered as desfavorable spaces in accordance with the EEC legislation. Factors that contribute to this consideration include altitude, declines, the weight of active agricultural population and still the intensity of recent population losses, to the point of soon becoming «Portugal of the emptyness». The passage through the border is accomplished only at certain points and involves overall men and goods with distant destinations and origins beyond the Pyrenese. However, people from both sides of the border 
have overcome its impermeability and integrated into their survival strategies the potential of all sorts of illegal acts, such as migration of workers in accordance with the opportunities of jobs (agriculture, construction, restaurants, etc.) and salaries, small business, whole sale business of domestic and imported goods, as local helpers who know well backroads and authorities and can therefore succeed in the evening contraband work. All of this activity was quite common along the border of Internal Beira, mainly rural and agricultural space, greatly touched by the exodus, covered by uncultivated land and woods, without any diversity of economy and employment, besides construction and its industries (new homes for the imigrants), and also the unproductive tertiary sector. Agricultural families have multi-jobs and their members eecupy the most non agricultural jobs. These families are also elderly, resulting: in many situations of multi-revenue without multi-occupations (retirement aid). During the 1970's and 1980's some inovations in the productive activites and infrastructures have bettered the local and regional standard of living and way of life. The integration into the EEC should allow the porsuit in this direction, intensifying the relations with people from the other side of the border, overcaming handicaps, mainly isolation and inaccessibility, by collaboration of efforts. The conjunctive elaboration of a development plan can be a turning point for their relations and the economic and social tendencies. These tendencies will also be altered in the country by the elaboration of a rural and agricultural development plan, which should allow a better coordination of initiatives taken under the shelter of the PEDAP or the Reg. 797. 


\section{ANEXO I}

Indicadores demográficos

\begin{tabular}{|c|c|c|c|c|}
\hline & Almeida & Sabugal & Penamacor & Idanha \\
\hline Densidade (hab. $/ \mathrm{km}^{2}$ ) (1981) & 20,1 & 22,9 & 17,0 & 11,4 \\
\hline Pop. isolada em lugares $<100$ hab. (\%) & 6,7 & 11,4 & 6,8 & 12,1 \\
\hline Pop. em lugares $\geqslant 2000$ hab. $(\%) \ldots .$. & 23,5 & - & - & 14,4 \\
\hline Dimensão média das familias ............ & 2,9 & 2,6 & 2,6 & 2,3 \\
\hline Taxa de masculinidade (\%). & 48,2 & 47,8 & 47,4 & 47,4 \\
\hline Populaçāo $<15$ anos HM ...... & $\mathbf{2 1 , 8}$ & $\mathbf{1 7 , 7}$ & 17,6 & 14,9 \\
\hline$(\%) \quad \mathbf{H} \ldots \ldots \ldots \ldots \ldots \ldots$ & 22,2 & 18,9 & 18,9 & 15,6 \\
\hline $\mathbf{M} \ldots \ldots \ldots \ldots \ldots \ldots$ & 21,4 & 16,6 & 16,4 & 14,4 \\
\hline População $\geqslant 60$ anos HM $\ldots$ & 24,1 & 30,8 & 31,1 & 35,5 \\
\hline $\mathbf{H} \ldots \ldots$ & 22,7 & 29,4 & 29,7 & 34,6 \\
\hline $\mathbf{M} \ldots \ldots \ldots$ & 25,4 & 32,1 & 32,3 & 36,3 \\
\hline Familias sem activos $(\%) \ldots$ & 32,1 & 37,7 & $\mathbf{4 2 , 7}$ & 46,8 \\
\hline Taxa de actividade $\mathbf{H M} \ldots$ & 34,2 & 38,0 & 34,1 & 30,7 \\
\hline$H \ldots \ldots \ldots \ldots \ldots \ldots \ldots$ & 54,5 & 53,4 & $5.1,1$ & $50 ; 6$ \\
\hline $\mathbf{M} \ldots \ldots \ldots \ldots \ldots \ldots \ldots$ & 15,3 & 24,0 & 18,8 & 12,9 \\
\hline Pop. activa/pop. $15-60$ anos HM .... & 63,2 & 73,8 & 70,2 & 62,0 \\
\hline & 99.0 & 103,2 & 99,4 & 101,6 \\
\hline $\mathbf{M} \ldots \ldots \ldots \ldots$ & 28,7 & 46,7 & 36,8 & 25,4 \\
\hline $\begin{array}{l}\text { Pop. activa agric., pec., silv. } \\
\text { - \% população } 15-60 \text { anos } \mathrm{HM}\end{array}$ & 27,2 & 43,9 & 34,3 & $31 ; 0$ \\
\hline $\mathbf{H} \ldots \ldots \ldots \ldots$ & 43,1 & 56,5 & 44,3 & 51,9 \\
\hline $\mathbf{M} \ldots \ldots \ldots \ldots$ & 11,8 & 32,2 & 21,9 & 11,7 \\
\hline — \% população activa $\mathrm{HM}$............. & 47,5 & 63,7 & 53,6 & 55,6 \\
\hline $\mathbf{H} \ldots \ldots \ldots$ & 47,7 & 58,8 & 48,3 & $\mathbf{5 5 , 2}$ \\
\hline $\mathbf{M} \ldots \ldots \ldots \ldots \ldots$ & 47,1 & 73,7 & 66,9 & $\mathbf{5 7 , 4}$ \\
\hline $\begin{array}{l}\text { Pop. que não mudou de concelho rela- } \\
\text { tivamente a } 1973 \text { (\%) HM .......... }\end{array}$ & 73,8 & 78,5 & 77,2 & 81,9 \\
\hline $\mathrm{H} \ldots \ldots \ldots \ldots$ & 72,4 & $\mathbf{7 5 , 8}$ & 74,1 & 80,2 \\
\hline $\mathbf{M} \ldots \ldots \ldots \ldots$ & 75,1 & 80,9 & 80,0 & 83,4 \\
\hline imigrantes do país (\%) HM .... & 5,7 & $\mathbf{3 , 7}$ & 7,0 & 5,0 \\
\hline $\mathbf{H} \ldots \ldots \ldots \ldots$ & 5,7 & 4,2 & 7,7 & 5,5 \\
\hline $\mathbf{M} \ldots \ldots \ldots \ldots$ & 5,7 & 3,2 & 6,3 & 4,5 \\
\hline imigrantes do estrangeiro $(\%) \mathrm{HM} .$. & 12,2 & 10,9 & 8,8 & 6,5 \\
\hline H... & 13,6 & 12,6 & 10,4 & 7,8 \\
\hline $\mathbf{M} \ldots \ldots$ & 11,0 & 9,3 & 7,3 & 5,2 \\
\hline
\end{tabular}


ANEXO I (Conţinuação)

\begin{tabular}{|c|c|c|c|c|}
\hline & Almeida & Sabugal & Penamacor & Idanha \\
\hline emigrantes do concelho para outros & & & & \\
\hline 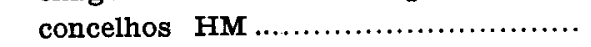 & 7,3 & 7,4 & 10,4 & 11,6 \\
\hline$(\%) \quad$ H..... & 6,7 & 6,2 & 9,3 & 10,5 \\
\hline 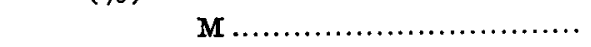 & 7,8 & 8,5 & 11,5 & 12,5 \\
\hline Variação demográfica $(\%) \quad 1950-60 \ldots \ldots$ & $-7,9$ & $-12,5$ & $-11,6$ & $-9,0$ \\
\hline $1960-70 \ldots \ldots$ & $-33,4$ & $-39,6$ & $-26,5$ & $-32,3$ \\
\hline $1970-81 \ldots \ldots$ & $-2,0$ & $-17,6$ & $-22,2$ & $-21,8$ \\
\hline Saldo migratório de 1981 , relativamente & & & & \\
\hline a 1973 (\% de pop. residente) HM ... & $+10,7$ & $+7,1$ & $+5,3$ & $-0,1$ \\
\hline H...... & $+12,6$ & $+10,6$ & $+8,8$ & $+2,8$ \\
\hline $\mathbf{M} \ldots \ldots$ & $+8,9$ & $+4,0$ & $+2,2$ & $-2,7$ \\
\hline Saldo migratório de 1981 , relativamente & & & & \\
\hline a 1979 (\% de pop. residente) HM ... & $+0,8$ & $+0,4$ & $+1,8$ & $-0,7$ \\
\hline $\mathbf{H} \ldots \ldots$ & $+1,2$ & $+10,7$ & $+2,3$ & $-0,3$ \\
\hline $\mathbf{M} \ldots \ldots$ & $+0,4$ & $-0,2$ & $+1,3$ & $-1,1$ \\
\hline $\begin{array}{l}\text { População que não mudou de concelho } \\
\text { relativamente a } 1979 \text { HM } \ldots \ldots \ldots \ldots \ldots \ldots\end{array}$ & 94,9 & 95,1 & 93,8 & 95,9 \\
\hline 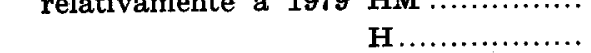 & 94,6 & 94,7 & 93,2 & 95,6 \\
\hline $\mathbf{M} \ldots \ldots \ldots \ldots \ldots$ & 95,1 & 95,5 & 94,3 & 96,3 \\
\hline $\begin{array}{l}\text { Retornos (HM) } \\
\quad \text { referentes a } 1979\end{array}$ & & & & \\
\hline 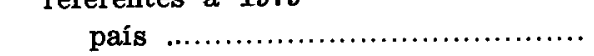 & 263 & 360 & 358 & 317 \\
\hline 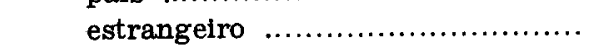 & 141 & 329 & 120 & 169 \\
\hline referentes a 1973 & & & & \\
\hline país ........................ & 599 & 691 & 662 & 801 \\
\hline estrangeiro .............................. & 1287 & 2062 & 837 & 1040 \\
\hline Saídas para outros concelhos & & & & \\
\hline 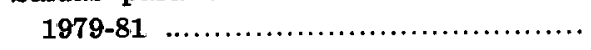 & 320 & 610 & 307 & 606 \\
\hline 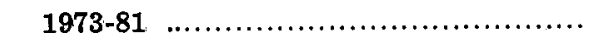 & 763 & 1400 & 993 & 1860 \\
\hline
\end{tabular}




\section{ANEXO II}

Freguesias com 30 ou mais activos no sector terciário

\begin{tabular}{|c|c|c|c|c|c|c|c|}
\hline \multirow{2}{*}{ Treguesias } & \multirow{2}{*}{$\begin{array}{l}\mathrm{N} .0 \text { de } \\
\text { activos } \\
\text { no ter- } \\
\text { ciário } \\
\text { (I) }\end{array}$} & \multirow{2}{*}{$\begin{array}{l}\text { Pop. } \\
\text { resi- } \\
\text { dente } \\
\text { (II) }\end{array}$} & \multirow{2}{*}{ I/II } & \multicolumn{2}{|c|}{$\begin{array}{c}\text { Serviços } \\
\text { de nat. social }\end{array}$} & \multicolumn{2}{|c|}{$\begin{array}{c}\text { Serviços relac. } \\
\text { actividades } \\
\text { económicas }\end{array}$} \\
\hline & & & & $\begin{array}{c}\text { N.0 } \\
\text { de act. }\end{array}$ & $0 / 0$ de I & de act. & $\%$ de 1 \\
\hline Almeida ......... & 237 & 1488 & 0,16 & 156 & 65,8 & 81 & 34,2 \\
\hline Nave do Haver ... & 55 & 766 & 0,07 & 31 & 56,4 & 24 & 43,6 \\
\hline Vilar Formoso ..... & 665 & 2464 & 0,27 & 267 & 40,2 & 398 & 59,8 \\
\hline A. $\mathbf{S}^{{ }^{t o}}$ António $\ldots$ & 57 & 644 & 0,08 & 30 & 52,6 & 27 & 47,4 \\
\hline Cerdeira .............. & 78 & 382 & 0,20 & 40 & 51,3 & 38 & 48,7 \\
\hline Sabugal ......... & 465 & 2181 & 0,21 & 251 & 54,0 & 214 & 46,0 \\
\hline Souto...$\ldots \ldots \ldots \ldots$ & 73 & 1208 & 0,06 & 30 & 41,1 & 43 & 58,9 \\
\hline A. Bispo ............ & 45 & 953 & $0,0.5$ & 26 & $\mathbf{5 7 , 8}$ & 19 & 42,2 \\
\hline A. J. Pires ..... & $3: 1$ & 466 & 0,07 & 23 & 74,2 & 8 & 25,8 \\
\hline Aranhas ....... & 38 & 678 & 0,10 & 19 & 50,0 & 19 & 50,0 \\
\hline Benquerença ........ & 45 & 942 & 0,05 & 9 & 20,0 & 36 & 80,0 \\
\hline Pedrógão ............ & 32 & 798 & 0,04 & 15 & 46,9 & 17 & 53,1 \\
\hline Penamacor .... & 357 & 2300 & 0,16 & 213 & 59,7 & 144 & 40,3 \\
\hline Salvador ........ & 68 & 884 & 0,08 & 44 & 64,7 & 24 & 35,3 \\
\hline Idanha-a-Nova ..... & 356 & 2742 & 0,13 & 215 & 60,4 & 141 & 39,6 \\
\hline Ladoeiro .............. & 103 & 1777 & 0,06 & 40 & 38,8 & 63 & 61,2 \\
\hline Medelim ......... & 47 & 525 & 0,09 & 19 & 40,4 & 28 & 59,6 \\
\hline Monfortinho .... & 141 & 885 & 0,16 & 32 & 22,7 & 1.09 & 77,3 \\
\hline Monisanto ............ & 64 & 1. 951 & 0,03 & 27 & 42,2 & 37 & 57,8 \\
\hline Oledo $\ldots \ldots \ldots \ldots \ldots$ & 39 & 69.6 & 0,06 & 23 & $\mathbf{5 9}, 0$ & 16 & 41,0 \\
\hline P. Garcia ......... & 65 & 1314 & 0,05 & 28 & 43,1 & 37 & 56,9 \\
\hline Rosmaninhal & 62 & 1134 & 0,05 & 34 & 54,8 & 28 & 46,2 \\
\hline S. Miguel Acha ... & 45 & 877 & 0,05 & 20 & 44,4 & 25 & 55,6 \\
\hline Segura ........... & 31 & 417 & 0,07 & 23 & 74,2 & 8 & 25,8 \\
\hline Zebreira .............. & 78 & 1352 & 0,06 & 41 & 52,6 & 37 & 47,4 \\
\hline
\end{tabular}




\section{ANEXO III}

Emprego feminino

\begin{tabular}{|c|c|c|c|c|c|c|c|c|c|c|c|c|}
\hline \multirow[b]{2}{*}{ Ramos de actividade } & \multicolumn{3}{|c|}{ Almeida } & \multicolumn{3}{|c|}{ Sabugal } & \multicolumn{3}{|c|}{ Penamacor } & \multicolumn{3}{|c|}{ Idanha } \\
\hline & 1960 & 1981 & $\begin{array}{c}1981 / 60 \\
(\%)\end{array}$ & 1960 & 1981 & $\begin{array}{c}1981 / 60 \\
(\%)\end{array}$ & 1960 & 1981 & $\begin{array}{c}1981 / 60 \\
(\%)\end{array}$ & 1960 & 1981 & $\begin{array}{c}1981 / 60 \\
(\%)\end{array}$ \\
\hline $\begin{array}{l}\text { Agricultura, silvicultu- } \\
\text { ra, caça e pesca ...... }\end{array}$ & 226 & 343 & 151,8 & 345 & 1636 & 474,2 & 73 & 562 & 7699 & 435 & 504 & 1159 \\
\hline $\begin{array}{l}\text { Indústria, s/construção } \\
\text { civil e obras públicas }\end{array}$ & 106 & 16 & 15,1 & 85 & 156 & 183,5 & 63 & 24 & 38,1 & 99 & 39 & 39,1 \\
\hline $\begin{array}{c}\text { Construção civil e obras } \\
\text { públicas ................ }\end{array}$ & 1 & 5 & 500,0 & 一 & 10 & - & 一 & 4 & - & 2 & 1 & 50,0 \\
\hline Comércio e serviços ... & 295 & 341 & 115,6 & 526 & 363 & 69,0 & 264 & 198 & 75,0 & 203 & 339 & 167,0 \\
\hline
\end{tabular}

Emprego masculino

\begin{tabular}{|c|c|c|c|c|c|c|c|c|c|c|c|c|}
\hline \multirow{2}{*}{ Ramos de actividade } & \multicolumn{3}{|c|}{ Almeida } & \multicolumn{3}{|c|}{ Sabugal } & \multicolumn{3}{|c|}{ Penamacor } & \multicolumn{3}{|c|}{ Idanha } \\
\hline & 1960 & 1981 & $\begin{array}{c}1981 / 60 \\
(\%)\end{array}$ & 1960 & 1981 & $\begin{array}{c}1981 / 60 \\
(\%)\end{array}$ & 1960 & 1981 & $\begin{array}{c}1981 / 60 \\
(1 \%)\end{array}$ & 1960 & 1981 & $\begin{array}{c}1981 / 60 \\
(\%)\end{array}$ \\
\hline $\begin{array}{l}\text { Agricultura, silvicultu- } \\
\text { ra, caça e pesca ...... }\end{array}$ & 3815 & 1205 & 31,6 & 9456 & 2642 & 27,9 & $|3,817|$ & 1029 & 27,0 & 7712 & 1972 & 25,6 \\
\hline $\begin{array}{l}\text { Indústria, s/construção } \\
\text { civil e obras públicas }\end{array}$ & 206 & 113 & 54,9 & 600 & 268 & 44,7 & 311 & 94 & 30,2 & 672 & 219 & 32,6 \\
\hline $\begin{array}{c}\text { Construção civil e obras } \\
\text { públicas } . . . \ldots \ldots \ldots \ldots \ldots\end{array}$ & 123 & 392 & 318,7 & 208 & 787 & 378,4 & 319 & 529 & 165,8 & $\mathbf{4 7 7}$ & 590 & 123,7 \\
\hline Comércio e serviços & 620 & 754 & 121,6 & 963 & 757 & 78,6 & 563 & 425 & 75,5 & 1053 & 733 & 69,6 \\
\hline
\end{tabular}

Taxa de feminização (\%)

Ramos de actividade

\begin{tabular}{|c|c|c|c|c|c|c|c|}
\hline \multicolumn{2}{|c|}{ Almeida } & \multicolumn{2}{|c|}{ Sabugal } & \multicolumn{2}{|c|}{ Penamacor } & \multicolumn{2}{|c|}{ Idanhe } \\
\hline 1960 & 1981 & 1960 & 1981 & 1960 & 1981 & 1960 & 1981 \\
\hline 5,9 & 28,5 & 3,7 & 61,9 & 1,9 & 54,6 & 5,6 & 25,6 \\
\hline 51,5 & 14,2 & 14,2 & 58,2 & 20,3 & 25,5 & 14,7 & 17,8 \\
\hline 47,6 & 45,2 & 54,6 & 48,0 & 46,9 & 46,7 & 19,3 & 46,2 \\
\hline
\end{tabular}

Agricultura, silvicultura, caça

e pesca

Indústria, s/ construção civil e obras públicas

Comércio e serviços
47,6
54,6 
Condição na profissão (1981) (\% de activos)

\begin{tabular}{|c|c|c|c|c|}
\hline de actividade & Almeida & Sabugal & Penamacor & Idanha \\
\hline \multicolumn{5}{|l|}{ Agricultura, silvicultura e caça } \\
\hline 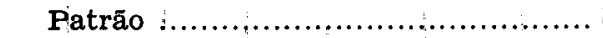 & 0,6 & 0,5 & 0,6 & 2,3 \\
\hline Trabalhador por conta própria .......... & 73,1 & 76,6 & 57,9 & 23,6 \\
\hline Trabalhador familiar não remunerado & $12 ; 5$ & 13,3 & 1,1 & 2,1 \\
\hline 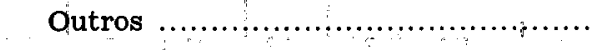 & 13,8 & 9,6 & 40,4 & 72,0 \\
\hline \multicolumn{5}{|l|}{ Construção civil e obras públicas } \\
\hline 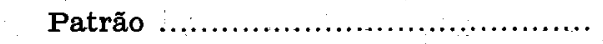 & 3,3 & 5,6 & 1,7 & 3,7 \\
\hline Trabalhador por conta própria .......... & 17,1 & $\mathbf{1 7 , 0}$ & 8,3 & 7,4 \\
\hline Trabalhador familiar nāo remunerado & 0,3 & 0,9 & 0,2 & 0,2 \\
\hline Outros & 79,3 & 76,5 & 89,8 & 88,7 \\
\hline \multicolumn{5}{|l|}{ Comércio a retalho } \\
\hline Patrão ............... & 9,2 & 7,2 & 11,7 & 3,4 \\
\hline Trabalhador por conta própria .......... & 57,3 & 72,2 & 66,7 & 73,7 \\
\hline Trabalhadơ familiar não remunerado & 3,2 & 3,8 & 1,2 & 3,0 \\
\hline$\ldots \ldots \ldots \ldots \ldots \ldots \ldots$ & 30,3 & 16,8 & $.20,4$ & 19,9 \\
\hline
\end{tabular}

Condição na profissão da população activa agrícola, segundo o sexo (1981, \%)

\begin{tabular}{|c|c|c|c|c|c|c|c|c|}
\hline \multirow{2}{*}{ Condiçōes na profisssão } & \multicolumn{2}{|c|}{ Almeida } & \multicolumn{2}{|c|}{ Sabugal } & \multicolumn{2}{|c|}{ Penamacor } & \multicolumn{2}{|c|}{ Idanha } \\
\hline & H & M & $\mathrm{H}$ & $\mathbf{M}$ & $\mathrm{H}$ & $\mathbf{M}$ & H & M \\
\hline Patrão & 0,7 & 0,3 & 0,8 & 0,1 & 0,8 & 0,2 & 2,8 & 0,6 \\
\hline $\begin{array}{l}\text { Trabalhador por conta pró- } \\
\text { pria }\end{array}$ & 77,3 & 58,2 & 77,8 & 74,5 & 53,3 & 66,4 & 24,0 & 22,6 \\
\hline $\begin{array}{l}\text { Trabalhador familiar não } \\
\text { remunerado }\end{array}$ & 6,6 & 33,6 & 10,7 & 17,2 & 1,1 & 1,1 & 1,6 & 4,0 \\
\hline $\begin{array}{l}\text { Trabalhador por conta dou- } \\
\text { trem }\end{array}$ & 15,4 & 7,9 & 10,7 & 7,9 & 44,8 & 32,1 & 69,8 & 72,8 \\
\hline 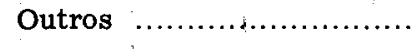 & - & - & 一 & 0,3 & - & 0,2 & 1,8 & - \\
\hline
\end{tabular}




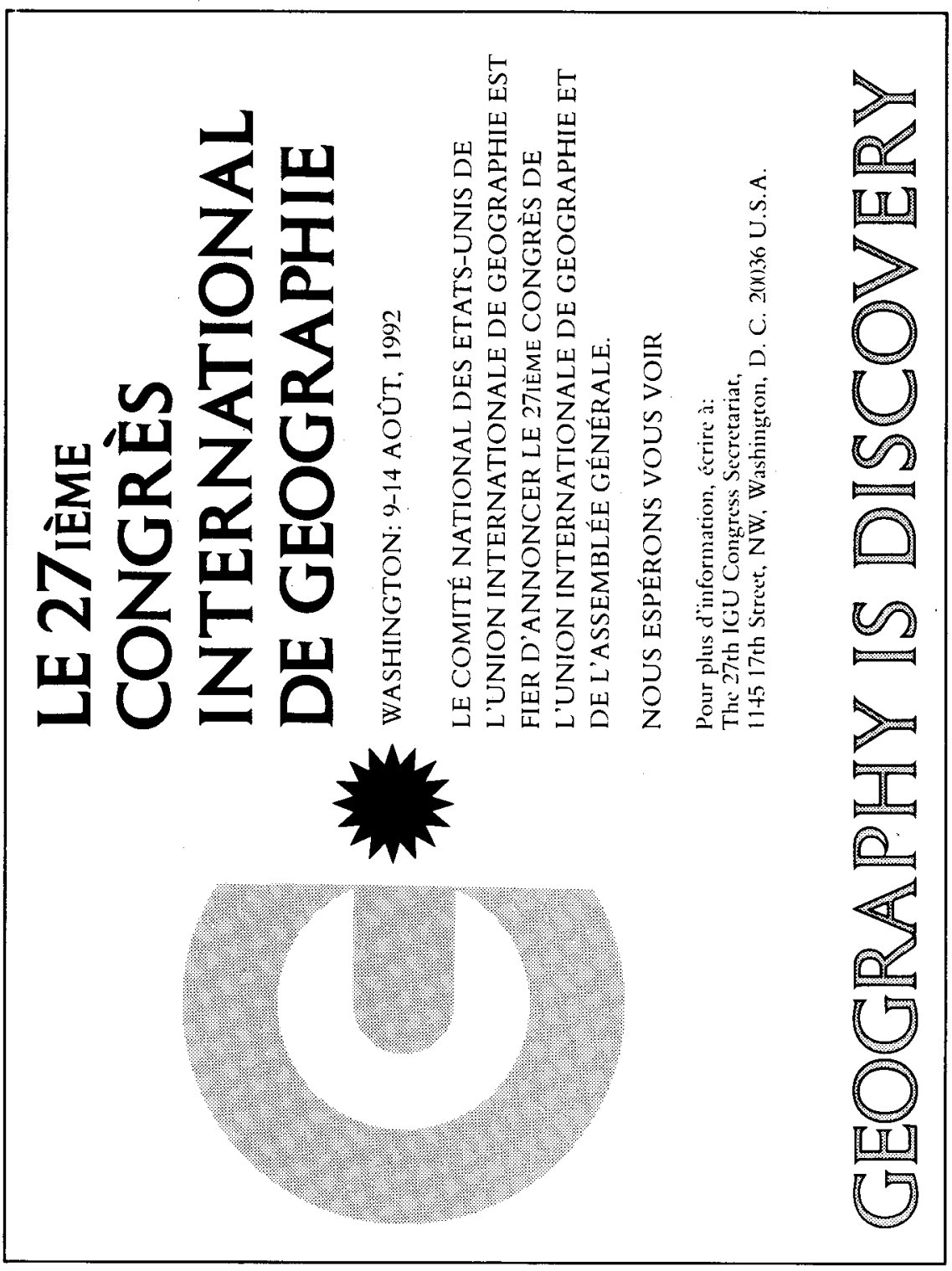

